Working Paper \#003/2020

\title{
Firm Diversification and Performance: An Empirical Examination*
}

\author{
Jorge Humberto Mota \\ School of Economics and Management of the University of Porto, Portugal \\ Department of Economics, Management, Industrial Engineering and Tourism \\ University of Aveiro, Portugal \\ jorgemota@ua.pt \\ Mário Coutinho dos Santos \\ Católica-Lisbon School of Business and Economics, Catholic University of Portugal \\ Universidade Autónoma de Lisboa, Portugal \\ mcsantos@autonoma.pt
}

\begin{abstract}
This paper examines several dimensions of the relationship between diversification and performance. Specifically, we investigate the link between related and unrelated diversification and performance. We also study the effect of the potential redeployment of 'plastic' assets on unrelated diversification. To investigate this, we estimated a dynamic panel on a data set of 2,396 diversified firms from the euro area, over the 2010-2017 sampling period. Empirical results indicate that an increase in the level of unrelated diversification, is significantly associated with an 0.65 percent improvement in performance, and related diversification with an 0.98 percent increase in performance. Additionally, we found that the level of unrelated diversification is positively and significantly impacted, 1.32 percent, by changes in the level of asset plasticity. Overall, our findings contribute to the corporate diversification literature by documenting that both, related and unrelated diversification, impact positively performance. Moreover, providing evidence consistent with the intuition that asset plasticity may be a positive factor for unrelated diversification strategies.
\end{abstract}

Keywords: firm performance; total/unrelated/related diversification; entropy measure of diversification; asset plasticity; multidivisional firm

JEL classification: C33; L22; L25; M10

* This paper is based on Jorge Mota's PhD thesis presented to Faculdade de Economia of the University of Porto, Portugal.

We are especially grateful to BVD for providing access to Amadeus database. The authors are responsible for all remaining errors and omissions. Jorge Mota is the corresponding author and can be reached atjorgemota@ua.pt.

This research did not receive any specific grant from funding agencies in the public, commercial, or not-for-profit sectors. 


\section{Introduction}

Pioneering contribution by Ronald Coase (1937), related firm boundaries to resource allocative efficiency, as a result of a dynamic balance between the costs of market and hierarchical coordination. Additionally, Maksimovic and Phillips $(2007,425)$ argue that the problem of setting firm boundaries is embedded in «the relation between diversification and value». ${ }^{1}$

As argued in transaction cost economics, the organizational forms of economic activity are a continuum of production coordination technologies, spanning between markets and hierarchies (e.g., Gertner and Scharfstein 2013; Milgrom and Roberts 1992). Under this framework, firms emerge as a trade-off between the costs of using the price system and the costs of using a hierarchical management system (e.g., Demsetz 1997).

There is widespread agreement that economic activity carried out within the boundaries of firms is quantitatively more significant, in terms of transactions, value added, and employment, than the ones conducted through markets (Walker 2017; Gertner and Scharfstein 2013; Lafontaine and Slade 2007). ${ }^{2}$

The examination of diversified firms' behavior, and of the ICMs through which resources are allocated, has received a great deal of attention from economists (e.g., Glaser et al. 2013; Maksimovic and Phillips 2013; Agarwal et al. 2011). However, even today, and despite the theoretical arguments and the empirical findings on the allocative efficiency of diversified versus single-segment firms, the topic still remains a theoretical and empirical challenge for the economic analysis of business organizations. ${ }^{3}$

There is also abundant evidence documenting the importance of diversified firms and ICMs, through which they operate as an organizational platform to perform their productive activities. For example: (i) «diversified firms comprise $75 \%$ on average of the market value

\footnotetext{
${ }^{1}$ For comprehensive discussions on a firm's boundaries please refer to, e.g., Hart and Holmström (2010), Mullainathan and Scharfstein (2001), Demsetz (1997), and Williamson (1975), and references cited therein.

${ }^{2}$ According to Leland $(2007,765)$ «[p]ositive or negative operational synergies are often cited as a prime motivation for decisions that change the scope of the firm. A rich literature addresses the roles of economies of scope and scale, market power, incomplete contracting, property rights, and agency costs in determining the optimal boundaries of the firm».

${ }^{3}$ Hereafter we use, interchangeably, diversified firm, multidivisional firm, conglomerates and business group, as an organizational structure coordinating a set of diversified and legally independent firms.
} 
of the S\&P 500» (Hund et al. 2012, 1); (ii) «business groups are ubiquitous in many countries» (Carney et al. 2011, 437); (iii) «chaebols are large business conglomerates in South Korea. Since the 1960s, they have played a major role in developing the Korean economy» (Lee et al. 2009, 327); (iv) «conglomerate firm production represents more than 50 percent of production in the United States» (Maksimovic and Philips 2007, 424); (v) «[t]here is ample evidence that large corporations operate an internal capital market» (Inderst and Laux 2005, 215); (vi) «[a] striking feature of most emerging economies is the prominent role played by business groups» (Khanna and Rivkin 2001, 45); (vii) «[d]diversified business groups dominate private sector activity in most emerging markets around the world» (Khanna and Palepu 2000, 867); and (viii) «[i]n Belgium, as in many other European countries, financial and industrial groupings and combines play a crucial role in the accumulation and allocation of capital in the economy» (Deloof 1998, 945). ${ }^{4}$

Despite diversified firms being a ubiquitous form of economic organization in the contemporary corporate world, «there is surprisingly little direct evidence on the efficiency of their capital allocation» (Almeida et al. 2015, 2539). Therefore, additional research may be necessary to enhance the explanatory relevance of extant theoretical predictions, and to improve the generalization power of empirical findings.

Does firm diversification matter? Or, as questioned by Maksimovic and Phillips $(2007,425)$, «[...] does corporate diversification affect firm value?». The answer to these important questions seems to be intimately linked to where firm boundaries are actually set, and therefore, to the efficiency of the type and extent of the diversification behavior (e.g., Williamson 1975). ${ }^{5}$

A plethora of theoretical and empirically based arguments indicate that diversification may have ambivalent effects on value (e.g., Campa and Kedia 2002; Berger and Ofek 1995).

\footnotetext{
${ }^{4}$ For further recent research on the relevance of diversified firms in the business organization world see, e.g., Buchuk et al. (2014), Belenzon et al. (2013), Gugler et al. (2013), Faccio and Lang (2002).

${ }^{5}$ As suggested by Maksimovic and Phillips $(2007,425)$, «for corporate diversification to be of interest, it must be that the cost of carrying out transactions within the firm are affected if it contains more than one industry within its boundaries».
} 
The economic performance of diversified firms with active ICMs, is related to the allocative efficiency of their investment and financing behavior (e.g., Gonenc et al. 2007). ${ }^{6}$ Furthermore, as suggested by Williamson (1975), «"internal capital markets" in diversified firms can allocate capital more efficiently than external capital markets can, and that they can reduce wasteful investment at lower cost» (Liebeskind 2000, 58).

Therefore, furthering our understanding on the impact of diversification on the economic performance of business organizations has great practical relevance and is assumed as the generic research question for the paper.

This paper examines the relationship between firms' overall, unrelated and related diversification levels and accounting- and market-based performance measures, using a panel data set of 2,396 euro area firms, over the 2010-2017 sampling period, in a total of 19,168 testable firm-years. We also examine the redeployment of 'plastic' assets across different business units may increase change in firms' unrelated diversification levels.

This paper contributes to the literature and distinguishes from prior research in different ways. Firstly, unlike mainstream literature, predominantly focused on U.S. and Asian firms, findings, investigating the diversification - performance relationship using a sample of euro area diversified firms, therefore enhance the generalization power of the empirical regularities (e.g., Villalonga 2004a; Chakrabarti et al. 2007; Ferris et al. 2003). By examining the impact of euro area diversified business organizations on their economic performance, we aim to contribute to mitigating the problems associated with differences in economic, financial, legal and institutional features typically associated with multi-country research, and to enhancing the generalization power of the inferences drawn from empirical findings.

Secondly, by examining a sample composed of 90,1 percent of unlisted and 9,9 percent of listed firms, statistically larger than unlisted ones, we contribute to mitigate the size bias normally associated with this mainstream literature.

\footnotetext{
${ }^{6}$ According to Thakor $(1993,135)$, in an «idyllic setting», it is irrelevant whether allocative decisions are made: «in a centralized or decentralized capital budgeting environment [regardless of] whether the project is included as part of the firm's portfolio of assets or organized outside the firm, i.e., incorporated as a subsidiary with a legal delineation from the firm's existing assets [and] how the project is financed».
} 
Thirdly, by analyzing the somewhat neglected relationship between asset plasticity and diversification, aiming at contributing to mitigating the misspecification problem associated with the omission of a potentially relevant independent variable from the empirical model.

The paper's main findings document that: (i) sampled diversified firms exhibit a positive and statistically significant relationship between the levels of overall, unrelated and related diversification and performance, which is consistent with prior research investigating U.S. and Asian listed firms (e.g., Giachetti 2012; Wan and Hoskisson 2003; Bettis 1981); (ii) a positive relation between overall, unrelated and related diversification and a market-based performance measure; and (iii) firms' asset plasticity levels exhibit a positive effect on the changes in the unrelated diversification levels, evidence that is consistent with prior research (e.g., Kim and Kung 2017; Shleifer and Vishny 1992; Williamson 1988).

The remainder of the paper is structured as follows: Section 2 discusses the relevant theoretical and empirical literature and formulates the hypotheses. Section 3 describes the data and the empirical implementation. Section 4 presents and analyzes univariate statistics and the results of econometric estimations. Section 5 documents robustness check results. Section 6 summarizes and provides concluding remarks.

\section{Background and Hypotheses}

\subsection{Introduction}

Beginning in the early 1920s, the U.S. witnessed the establishment of diversified business organizations - the 'M-Form' - pioneered by the DuPont Company and General Motors (Williamson 1975). Since then, this phenomenon has gained momentum, and diversified firms have gathered a geographically widespread significant economic role (e.g., Montgomery 1994).

A crucial question when studying diversification is naturally, why do firms diversify? According to extant literature, firms diversify in order to improve the economic performance of the resources they have under control (e.g., Giachetti 2012; Chatterjee and Wernerfelt 1991; Ramanujam and Varadarajan 1989). A distinct but related question asks 
what are the reasons that may lead firms to become involved in diversifying their productive activities? The answer to this question has attracted the interest and has nurtured an ongoing debate among academics and practitioners alike.

Prior research has enlightened various arguments rationalizing firm diversification. A number of them anchored on the seminal contributions of Coase (1937) and Williamson (1975), on resource allocative efficiency in general, and on the diversified firm (M-form) in particular (see also Liebeskind 2000). ${ }^{7}$ On this theoretical perspective, diversification is beneficial whenever the costs of carrying out transactions under an organizational arrangement of a group of coordinated 'hierarchies', is lower than carrying them out in a set of independent 'hierarchies'. Therefore, diversification may be a source of value creation (e.g., Rumelt 1974; Chandler 1962). ${ }^{8}$

However, and despite the accumulated research, still remains an empirical question whether resource usage is more efficient within a diversified organization, or through a set of contracts with independent firms.

Nonetheless, the theoretical and empirically based arguments suggesting that diversification may affect value ambivalently (e.g., Campa and Kedia 2002), findings from prior research document that firms involved in either diversification or refocusing strategies exhibit improvements in economic performance (e.g., Steiner 1997; Hansen and Wernerfelt 1989; Lecraw 1984). ${ }^{9}$

The most ubiquitous diversification strategies observed in the real corporate world include: (i) related versus unrelated diversification (e.g., La Rocca et al. 2018; Markides and Williamson 1994; Chatterjee and Wernerfelt 1991; Bettis 1981); (ii) domestic versus international diversification (e.g., Borda et al. 2017; Gaur and Kumar 2009; Freund et al. 2007; Thomas 2006; Lu and Beamish 2004; Capar and Kotabe 2003; Denis et al. 2002; Hitt et al. 1997; Riahi-Belkaoui 1996; Tallman and Li 1996; Kim et al. 1993); (iii)

\footnotetext{
${ }^{7}$ According to Coase (1937) and Williamson (1975), economies of scope in resources and capabilities can be reached by: (i) selling or licensing them to another firm; (ii) reallocating those resources, depending on their 'plasticity', to another activity (see also, Wade and Gravill 2003).

${ }^{8}$ According to Maksimovic and Phillips $(2007,425)$ «the relation between diversification and value arise naturally from the larger problem of determining how the boundaries of firms should be set».

${ }^{9}$ We use, interchangeably, refocusing, reverse diversification or downscoping.
} 
diversification versus refocusing (e.g., Ferris et al. 2002; Matsusaka and Nanda 2002; Markides 1995; Hoskisson and Hitt 1994); and (iv) organic versus external diversification (e.g., Custódio 2014; Leland 2007; Goudie and Meeks 1982; Amihud and Lev 1981; Mueller 1977). ${ }^{10,11}$

\subsection{Firm Diversification and Performance}

\subsubsection{Determinants of Diversification}

What are the main determinants of firm diversification behavior? Prior research has identified market structure and firm conduct, as major determinants of firms' diversification behavior, and ultimately of their economic performance implications (e.g., Scherer and Ross 1990; Greening 1980; Porter 1980; Bain 1959).

In this perspective, the competitive positioning of a firm is contingent upon the structure of the industry it integrates and on its own conduct, both yielding a random level of performance. As argued by Schumpeter (1942), a firm's competitors strive to erode its competitive advantage, creating the incentive for the firm to adopt innovative strategic and operating behavior, 'the conduct', aiming at sustaining or enhancing its economic performance, and therefore softening the adverse 'creative destruction' effects of the «Schumpeterian world of innovation-based competition, price/performance rivalry, [and] increasing returns» (Teece et al. 1997, 509).

The performance outcome of a firm's conduct in creative destruction competition world, may either have a 'bright side' or a 'dark side'. The former, resulting in sustaining or enhancing its competitive positioning, and therefore economic performance. The latter, unable to sustain its competitiveness, will underperform in terms of shareholder value creation. Therefore, and under the assumption that economic performance and share price

\footnotetext{
${ }^{10}$ In a related diversification strategy, a firm expands its activity to closely related industries, e.g., that share technological or commercial similarities. When a firm expands by adding new products or services, technologically or commercially unrelated to its current portfolio of business activities, it is adopting an unrelated diversification strategy. Firm's activities may be spread out across international borders when adopting an international diversification strategy. Related and unrelated diversification strategies may be implemented through internal / organic growth within the organization, using internal resources to develop new business areas, or acquiring growth externally, for example, through merger and acquisitions.

${ }^{11}$ For a more in-depth analysis of this topic, please refer to, among others, Erdorf et al. (2013), Martin and Sayrak (2003), Datta et al. (1991), and references cited therein.
} 
are strongly and positively correlated, a firm could become an attractive proposition for 'firm value arbitrageurs', present in the market for corporate control (e.g., Manne 1965). ${ }^{12}$

The degree of competition in an industry depends on its underlying structure, represented by what Porter $(1989,1979)$ specified as the 'competitive forces', the collective interaction of which determines the potential economic performance of the industry. ${ }^{13} \mathrm{~A}$ firm's exposure to those forces, influences its conduct in response to the industry structure (e.g., Porter 1981; Berry 1974). ${ }^{14}$

A firm's conduct is simultaneously impacted by exogeneous factors, the industry structure, and endogenous factors, the base of available organizational resources and capabilities. In this framework, the firm's performance depends on specific characteristics, namely, scarcity and imperfect mobility, of its resources and distinctive capabilities (e.g., Teece 1984; Wernerfelt 1984; Penrose 1959). Firms use those capabilities, competencies and other assets to accommodate the dynamics of rapidly changing environments (Teece at al. 1997), and by developing innovative and difficult-to-replicate combinations of organizational, functional and technological skills as sources of competitive advantage. ${ }^{15,16}$

Diversification is a commonly used strategy for firms redeploying their assets in place or their growth assets (assets that the firm is expected to invest in the future), to their best usages. This asset reallocation, however, is contingent, among other factors, on the assets' level of 'plasticity'. ${ }^{17}$ Alchian and Woodward $(1988,69)$ «call resources or investment "plastic" to indicate that there is a wide range of discretionary, legitimate decisions within which the user may choose». Therefore, the higher the degree of asset

\footnotetext{
${ }^{12}$ We are assuming the presence of semi-strong informationally efficient markets (Fama 1970).

${ }^{13}$ Threat of new entrants in the industry; Bargaining power of buyers; Bargaining power of suppliers; Threat of substitute products and services; and rivalry among market participants.

14 Without loss of generality, henceforth, we will use 'market structure' and 'industry structure' interchangeably.

${ }^{15}$ According to Wang and Ahmed (2007), a firm's dynamic capabilities include factors such as adaptive capability, absorptive capability and innovative capability as well as firm-specific processes such as integration, reconfiguration, renewal, and recreation.

${ }^{16}$ Even though a firm does not possess a competitive advantage based on scarcity and imperfect mobility of its resources, it may still create value through 'sharing' resources and capabilities across different businesses. Sharing a common tangible or intangible resource, e.g., a single facility or brand, among several businesses, using a hierarchical governance, may confer economies of scope through the elimination of duplications and lowering marginal costs. For more details on dynamic capabilities, see also, Teece et al. (1997).

${ }^{17}$ See also Gossy (2008), Alchian and Woodward (1987), Franke (1987), Scott (1987), and Marschak (1938).
} 
plasticity or redeployability, the larger the opportunity set for reallocating those resources to other business opportunities with higher growth prospects and / or lower expected business risk (e.g., Kim and Kung 2017; Montgomery 1994; Shleifer and Vishny 1992; Williamson 1988).

\subsubsection{Determinants of Economic Performance}

Value creation is a widely accepted metric for a firm's economic performance, the main determinants of which are market structure characteristics, industry affiliation, and organizational factors (e.g., Otley 1999; Stimpert and Duhaime 1997; Hansen and Wernerfelt 1989; Schmalensee 1985; Scherer 1980; Bain 1956).

Under this framework, the operating cash flow streams and the cost of capital are the key drivers of value creation associated with diversification strategies (e.g., Grant 2016; Morin and Jarrell 2000).

\subsubsection{Diversification and Performance}

Although it is an extensively researched topic, the literature still does not provide unambiguous, convincing and widely accepted evidence about the nature, the signal and the magnitude of the relationship between diversification and performance (e.g., La Rocca et al. 2018; Singh et al. 2007; Villalonga 2004a, 2004b; Campa and Kedia 2002; Palich et al. 2000; Berger and Ofek 1995; Lang and Stulz 1994). ${ }^{18}$

A stream of the literature, popularized as the 'bright side' of diversification, argues that diversification is positively related to performance, therefore promoting diversification allocative efficiency (e.g., Almeida and Wolfenzon 2006; Khanna and Tice 2001; Sapienza 2001). This proposition is anchored in the following arguments: (i) a portfolio of business units, a conglomerate, that generates imperfectly correlated operating cash flows across its members, will exhibit a lower overall business risk, than a single firm operating a comparable set of productive activities, the so-called coinsurance effect (e.g., Jia et al. 2013; Maksimovic and Phillips 2013; Tong 2012; Kim and McConnell 1977; Lewellen 1971); (ii) sharing resources and capabilities across business units, and benefiting from expanded business portfolio diversification gains, market power gains and bankruptcy risk

\footnotetext{
${ }^{18}$ For further findings see Villalonga (2003) and Graham et al. (2002) and references therein.
} 
reduction, may generate operating and financial synergies (e.g., Gatzer et al. 2014; Hann et al. 2013; Fang et al. 2007; Leland 2007; Gomes and Livdan 2004; Liebeskind 2000; Montgomery 1985; Teece 1980; Kim and McConnell 1977; Williamson 1975; Lewellen 1971); (iii) increased monitoring incentives, greater availability and better information quality associated to headquarters exercising control rights (Khanna and Tice 2001; Scharfstein and Stein 2000; Lamont 1997; Stein 1997; Berger and Ofek 1995; Gertner et al. 1994; Hart and Moore 1990; Williamson 1985; Alchian 1969); (iv) the managerial headquarters' active winner-picking behavior (Stein 1997; Gertner et al. 1994; Williamson 1975); (v) effectiveness and efficiency in reallocating capital (e.g., Cline et al. 2014; Maksimovic and Phillips 2002; Matsusaka and Nanda 2002; Khanna and Tice 2001); (vi) the positive value-enhancing role that internal funding plays in adverse states of external capital markets (Santioni et al. 2017; Stein 1997; Williamson 1975); and (vii) 'softeners' of the financial constraints inherent to external capital markets (Maksimovic and Phillips 2007; Graham et al. 2002; Lee and Lee 2002; Erickson and Whited 2000; Lewellen 1971).

Empirical findings of another stream of research are consistent with the argument that the value of diversified firms may be discounted by the market, in relation to their fair value as a portfolio of comparable specialized firms (e.g., Anjos 2010; Servaes 1996; Berger and Ofek 1995; Lang and Stulz 1994). Potential failures of ICMs' financing and investment policies are often interpreted as the source of a 'conglomerate discount'. ${ }^{19}$

This stream of research espouses the diversification inefficient viewpoint, popularized as the 'dark side' of diversification, (e.g., Ozbas and Scharfstein 2010; Scharfstein and Stein 2000; Rajan et al. 2000). ${ }^{20}$ This branch of literature suggests: (i) conflicts of interest, informational and incentive problems in the subsidiary's and headquarters' managerial agency relationships, that may lead to allocative inefficiency, for example, cross-subsidizing unprofitable projects (Cline et al. 2014; Ozbas and Scharfstein 2010; Wulf 2009; Yan 2006; Scharfstein and Stein 2000; Rajan et al. 2000; Lins and

\footnotetext{
${ }^{19}$ The literature documents a significant diversification discount of 10 percent in Japan, 15 percent in the UK, and no significant diversification discount in Germany. According to Lins and Servaes (1999), the diversification discount seems robust to different sampling periods and firms' geographical origin.

${ }^{20}$ For a more in-depth analysis of this topic, see, e.g., Maksimovic and Phillips (2013), Martin and Sayrak (2003), Stein (2003), and Gertner et al. (1994).
} 
Servaes 1999; Rajan and Zingales 1998; Shin and Stulz 1998; Bodnar et al. 1997; Lamont 1997; Berger and Ofek 1995; Meyer et al. 1992; Jensen 1986); (ii) suboptimal capital allocation of diversified versus comparable single-industry firms (e.g., Billett and Mauer 2003, 2000; Shin and Stulz 1998; Berger and Ofek 1995); and (iii) corporate governance problems associated to centralized capital budgeting systems (e.g., Sautner and Villalonga 2010); and (iv) subsidiary managers may become involved in rent-seeking behavior, bargaining for larger suboptimal capital allocations for their units (Seru 2014; Glaser et al. 2013; Wulf 2009; Rajan et al. 2000; Scharfstein and Stein 2000; Meyer et al. 1992).

More recent research casts doubt on the diversification discount, based on evidence suggesting the presence of a 'diversification premium'. Furthermore, this stream of the literature suggests that previous findings may suffer from sample-selection bias (e.g., Hund et al. 2019; Villalonga 2004a, 2004b; and Graham et al. 2002), and measurement errors (e.g., Whited 2001). Moreover, as argued in Campa and Kedia (2002, 1731), the «documented discount on diversified firms is not per se evidence that diversification destroys value». ${ }^{21}$

Another line of research, documents that reverse diversification may be valueenhancing (e.g., Dittmar and Shivdasani 2003; Gertner et al. 2002; Berger and Ofek 1999; Markides 1995, 1992; and Hoskisson and Johnson 1992).

Firm diversification, and its implications in terms of value creation, may be 'reflected' in profitability (e.g., Palich et al. 2000; Rumelt 1974). Prior research documents that the levels of related and unrelated diversification are associated with different levels of firm profitability. According to, e.g., Wernerfelt and Montgomery (1988), Varadarajan and Ramanujam (1987), Palepu (1985), Rumelt (1974), related diversification should be more profitable than unrelated diversification. Bettis and Hall (1982) and Christensen and Montgomery (1981) argue that the differences in profitability between Rumelt's diversification categories could be mainly attributed to industry effects. The geographical scope of diversification may also have an impact on the relationship between

\footnotetext{
${ }^{21}$ Çolak $(2010,423)$ finds «no evidence of 'diversification discount' or 'refocusing premium'».
} 
diversification and performance (e.g., Denis et al. 2002; Hitt et al. 1997; Tallman and Li 1996; Kim et al. 1993).

However, empirical findings on the relationship between the level of diversification and performance seems to be sensitive to choices concerning performance measures, sample choice, sampling period, variable specification, method of analysis, firms' characteristics, industry affiliation, and the effectiveness and efficiency of allocative features of, e.g., the financial and legal systems (e.g., Ahn 2011; Çolak 2010; Fauver et al. 2003).

Findings of non-U.S. firm samples, mostly Asian (e.g., Bae et al. 2011; Wade and Gravill 2003), and European (e.g., La Rocca et al. 2018; Luffman and Reed 1984), also suggest the presence of some kind of ambivalence.

\subsubsection{Diversification and Performance Measures}

In this study, we only focus on quantitative measures of diversification. The number of business activities in which a firm operates, is one of the most used quantitative diversification measures (e.g., Farjoun 1998; Montgomery 1982). However, due to the lack of information provided by this measure, other metrics are suggested in the literature, among them: (i) the product specialization ration (e.g., Rumelt 1974); (ii) the Herfindahl index (e.g., Hitt et al. 2006; Kor and Leblebici 2005; Denis et al. 2002; Lang and Stulz 1994; Grant et al. 1988; Utton 1977; Berry 1971); (iii) the concentric index (e.g., Wernerfelt and Montgomery 1988; Caves et al. 1980; Pomfret and Shapiro 1980); and (iv) the entropy index (e.g., La Rocca et al. 2018; Chakrabarti et al. 2007; Singh et al. 2007; Hitt et al. 1997; Markides 1995; Chatterjee and Wernerfelt 1991; Varadarajan and Ramanujam 1987; Palepu 1985; Jacquemin and Berry 1979).

Extant literature that focuses on an empirical examination of a firm's performance documents that the metrics of performance mostly used in prior research are, either marketbased, or accounting-based. The former category encompasses the stock market reaction to the announcement of diversifying events; and the latter, includes profitability and associated risk measures, such as, the return on assets (ROA), the return on equity (ROE), and the return on sales (ROS).

\subsection{Hypothesis Development}


As argued by Williamson (1975), diversified firms may exhibit a better performance than undiversified firms, due to potential operating and financial synergies (e.g., Gatzer et al. 2014; Hann et al. 2013; Leland 2007; Gomes and Livdan 2004; Teece 1980; Kim and McConnell 1977; Lewellen 1971).

Findings using accounting-based performance measures, spanning a wide range of sampling periods, suggest the presence of a positive relationship between diversification and performance (e.g., George and Kabir 2012; Khanna and Rivkin 2001; Pandya and Rao 1998; Grant and Jammine 1988; Grant et al. 1988; Carter 1977). This pattern of findings seems more ubiquitous in tests of non-U.S. firm-level samples.

However, as argued in, e.g., Scharfstein and Stein (2000), Denis et al. (1997), and Jensen (1986), the presence of free cash-flow in diversified firms, may yield negative impacts on the level of their economic performance because of agency problems associated with managerial discretion. Empirical evidence, gathered through market-based performance metrics, spanning a wide range of sampling periods, documents a negative relationship between diversification levels and performance (e.g., Singh et al. 2007; Ferris et al. 2003; Lang and Stulz 1994; Montgomery and Wernerfelt 1988). This pattern of findings seems more ubiquitous in tests of U.S. firm-level samples.

Under the standard assumption that firms diversify with the aim of improving their overall economic performance (e.g., Giachetti 2012; Chatterjee and Wernerfelt 1991; Ramanujam and Varadarajan 1989; Teece 1984; Penrose 1959), and following the branch of literature that documents that the benefits of diversification outweigh the costs, (e.g., George and Kabir 2012; Khanna and Rivkin 2001; Grant et al. 1988), we hypothesize a positive relationship between diversification and performance levels - Hypothesis 1 (H1).

Conventional wisdom suggests that firms may undertake diversification strategies aiming at improving their performance in terms of value creation, by exercising diversification options, e.g., on assets-in-place or growth-opportunities. For example, by enlarging their boundaries into other related or unrelated products and/or markets, capturing operating and financial synergies, benefiting from market power, and / or reaping economies of scale (e.g., Hann et al. 2013; Devos et al. 2008; Leland 2007; Gomes and 
Livdan 2004; Sapienza 2002; Liebeskind 2000; Kim and Singal 1993; Teece 1980; Kim and McConnell 1977; Williamson 1975; Lewellen 1971).

More recent research suggests that growth-opportunity diversification options may be helpful in explaining the diversification-performance relationship (e.g., de Andrés et al. 2017, 2016, 2014; Borghesi et al. 2007).

La Rocca et al. (2009), Menéndez-Alonso (2003), and Bergh (1997), among others, argue that the coinsurance effect is expected to be more intense in unrelated diversified firms (see also Chatterjee and Wernerfelt 1991).

Prior research, based on accounting-based performance measures, reports that related diversified firms exhibit higher levels of performance than unrelated diversified firms (e.g., Wade and Gravill 2003; Palich et al. 2000; Wernerfelt and Montgomery 1988; Varadarajan and Ramanujam 1987; Palepu 1985; Lecraw 1984; Bettis 1981). Another stream of this literature documents that unrelated diversified firms perform better compared to related diversified firms (e.g., La Rocca et al. 2018; Bae et al. 2011; Hoskisson 1987; Luffman and Reed 1984; Michel and Shaked 1984).

Since related diversification appears to be more associated with positive operating synergies, and unrelated diversification more associated with positive financial synergies, we hypothesize a positive relationship between diversification, both unrelated and related, and firm performance (e.g., Leland 2007; Gomes and Livdan 2004; Teece 1980; Lewellen 1971) - Hypothesis 2 (H2).

Diversification strategies may, arguably, improve the performance of portfolios of firm-specific organizational, functional and technological resources and capabilities. Additionally, redeploying firms' assets may be helpful in allocating them to their most efficient usages (e.g., Teece at al. 1997).

However, asset reallocation is contingent on their degree of 'plasticity' (e.g., Kim and Kung 2017; Montgomery 1994; Alchian and Woodward 1988; Williamson 1988). We expect that, the higher the degree of asset plasticity, the larger the set of opportunities for reallocating those resources to other business opportunities with higher value creation prospects. To test the theory that reallocating 'plastic' assets across different business units increases the unrelated level of diversification, we hypothesize a positive relationship 
between the degree of asset plasticity and the unrelated level of diversification Hypothesis 3 (H3).

\section{Data Description and Empirical Specification}

\subsection{Sample Selection and Data Description}

For this empirical investigation, we developed a sample of diversified firms from euro area countries drawn from Bureau van Dijk's Amadeus database, for the 2010-2017 sampling period.

In this essay, we espouse the concept of a business group, as an entity coordinating a set of diversified and legally independent firms with a network of business and financial relationships of varying degrees and kinds (e.g. Khanna and Rivkin 2001). ${ }^{22}$

Amadeus database contains financial data of European diversified firms and their European subsidiaries. It also includes ownership data on subsidiaries outside European countries, but not their financial statement data. Therefore, our sample consists of data of euro area diversified firms and their euro area subsidiaries only.

To be included in the sample, firms had to satisfy the following criteria: (i) to be a non-financial Global Ultimate Owner (GUO), and other diversified firms that although they were not a GUO, hold, directly and / or indirectly, a minimum 50.01 percent ownership in any subsidiary, and own two or more subsidiaries; ${ }^{23}$ (ii) to be established in the euro area; (iii) to be active for the entire sampling period, with at least 6 to 8 years of data for all the variables, to ensure a balanced panel; ${ }^{24}$ and (iv) to have annual sales revenue higher than 20

\footnotetext{
${ }^{22}$ Like other papers with a similar focus and that used the Amadeus database, subsidiaries' data do not include segment data reported on 'behalf' of the 'parent' firm. Most papers on diversified firms use firm segment data (U.S. conglomerate information) that may introduce measurement errors in variables. See, e.g., Whited (2001) for more details.

${ }^{23}$ This classification criterion is based on a strong concept of ownership, which enables us to observe situations in which the parent firm has enough authority to control the investment and financing choices of its subsidiaries.

${ }^{24}$ Similar studies included in their samples only firms that had data available for the whole period or for at least six consecutive years (e.g., Dewaelheyns and Van Hulle 2012; La Rocca et al. 2009).
} 
million Euros. ${ }^{25}$ All financial service firms, education and regulated utilities were excluded from the sample.

Using the abovementioned selection criteria, we build our sample of diversified firms including 2,396 parent firms with 19,168 firm-year observations. In our sample, the average number of subsidiaries per diversified firm is 5 , and the max is $139{ }^{26}$

The specification of the firm-specific variables is presented in subsection 3.2. In order to mitigate the potential influence of extreme observations, data were winsorized according to the following criterion: whenever both market-to-book ratio and Tobin's $q$ were greater than 15 the firm was dropped from the sample (e.g., George et al. 2011; Cleary 1999).

\subsection{Implementation Design and Testing}

This subsection describes the specification of the empirical model, the variables and the methodology applied in hypotheses testing.

To test the effect of the firm diversification level on firm performance (H1), we estimated the following regression model:

Performance $_{i t}=\beta_{1}$ Performance $_{i t-1}+\beta_{2} L D_{i t}+\beta_{3}$ FinLev $_{i t}+\beta_{4}$ Size $_{i t}+\beta_{5}$ Tang $_{i t}+$ $+\beta_{6} M t o B_{i t}+\varepsilon_{i t}$

where Performance $_{i t}$ denotes firm performance; $L D_{i t}$, firm diversification level; FinLev ${ }_{i t}$, financial leverage; Size $_{i}$, firm size; Tang $_{i t}$, firm tangibility; Mto ${ }_{i t}$, growth opportunities; industry and time dummy variables; subscripts refer to firm $i$ at time $t$; and, $\varepsilon_{i t}$ is a disturbance term (e.g., George and Kabir 2012; Khanna and Palepu 2000). See table 1 for variables specification, and expected and estimated variable coefficient signs. ${ }^{27}$

\section{[Insert Table 1 here]}

\footnotetext{
${ }^{25}$ We exclude very small firms from our estimation sample, whose ownership and financial data may miss and may cause bias.

${ }^{26}$ Compared with previous studies, our sample, in general, focuses on an increased number of business groups, and is also based on a longer period (e.g., La Rocca et al. 2018; George and Kabir 2012; Kim et al. 2004; Khanna and Palepu 2000; Chatterjee and Wernerfelt 1991; Grant et al. 1988; Varadarajan and Ramanujam 1987; Montgomery 1985; Palepu 1985; Lecraw 1984).

${ }^{27}$ Since larger firms can take more advantage from, e.g., economies of scale and, ceteris paribus, be more profitable, size and tangibility of a firm may have a positive impact on a firm's performance level. Due to the trade-off between tax shields and bankruptcy costs, leverage may have a negative relationship with accounting measures of performance and a positive relationship with market measures (see, e.g., George and Kabir 2012; Khanna and Palepu 2000).
} 
Despite the context and the methodological implementation, a firm performance variable proxied through an accounting-based measure should be anchored in a risk-return framework. Therefore, for this study we adopted adjusted asset betas, for a firm's specific financial leverage, as the accounting-based risk measure, scaling all regressed variables by this risk measure: ${ }^{28}$ we estimated the systematic risk of a firm's assets, the asset beta $\left(\beta_{A}\right)$, as a measure of the operating cash-flow relative volatility generated in a business activity and represented by the coefficient of variation of operating cash flow (e.g., Kale et al. 1991; Gabriel and Baker 1980; and Beaver and Manegold 1975).

Underlying this procedure is the assumption that firms in the same industry tend to exhibit similar business risk levels (e.g., He and Kryzanowski 2007; Kaplan and Peterson 1998; Alexander et al. 1996). Accordingly, firms in our sample were grouped into industry categories according to their NACE code, and for each industry an asset beta was estimated as the weighted (by total net assets) average of the individual firm's business risk.

Asset betas were then adjusted for a firm's specific financial leverage, using Hamada's (1972) procedure:

$\beta_{E}=\beta_{A}\left(1+(1-t)\left(\frac{D}{E}\right)\right)$

where $\beta_{A}$ denotes the asset beta, the $\beta_{E}$ the equity beta, $D$ the market value of debt, $E$ the market value of equity and $t$ the marginal corporate tax rate on the firm's income, specified as the income tax expenses divided by income before tax.. Hamada's approach simply adjusts the asset beta (business risk) for the firm's after tax financial risk measured by its debt-equity ratio.

The explanatory variable total diversification level for firm $i, L D$, measures a firm's diversification levels using the 'entropy diversification index', firstly proposed by

\footnotetext{
${ }^{28}$ This transformation also allows the cross-section heterogeneity to be mitigated, like the transformation commonly applied in the literature of dividing all the measures included in a regression by the same firm measure, e.g., its total net assets.
} 
Jacquemin and Berry (1979), to analyze the relationship between corporate diversification and growth, (see also, e.g., Palepu 1985). ${ }^{29}$

The entropy index as a measure of a firm's diversification level, simultaneously considers the number of subsidiaries in which a diversified firm operates, the distribution of a firm's total sales across industry subsidiaries, and the identification of the degree of relatedness among the various subsidiaries. According to, e.g., La Rocca et al. $(2018,65)$, the entropy index allows «the objectivity of the product-count measures to be combined with the ability to apply the relatedness concept categorically, weighting the businesses by the relative size of their sales» (see also Palepu 1985). This measure provides three diversification indices for each firm: (i) the total diversification index; (ii) the related diversification index; and (iii) the unrelated diversification index.

Following Palepu (1985), we estimated the total entropy diversification index $(L D)$, as:

$$
L D=\sum_{i=1}^{N} P_{i} \times \ln \left(1 / P_{i}\right)
$$

where $P$ refers to the share of the $i^{\text {th }}$ subsidiary in the total sales of the diversified firm. ${ }^{30}$

As hypothesized, we expect a positive relationship between, both unrelated and related diversification levels, and firm performance (H2). To test this hypothesis, we estimated the following version of model 1 :

Performance $_{i t}=\beta_{1}$ Performance $_{i t-1}+\beta_{2} R D_{i t}+\beta_{3} U D_{i t}+\beta_{4}$ FinLev $_{i t}+\beta_{5}$ Size $_{i t}+\beta_{6}$ Tang $_{i t}+$ $+\beta_{7} M t o B_{i t}+\varepsilon_{i t}$

where $R D_{i t}$ denotes the related diversification index, estimated from subsidiaries in different 3- or 4-digit businesses within a 2-digit industry group; and $U D_{i t}$ the unrelated diversification index estimated from subsidiaries in different 2-digit industry groups (e.g., Palepu 1985; and Jacquemin and Berry 1979).

\footnotetext{
${ }^{29}$ As argued by Pomfret and Shapiro (1980, 145), «[o]ther measures of diversification could be calculated, but the reward is small because the measures tend to be correlated».

${ }^{30}$ For more details on the entropy measure see Palepu (1985) and Jacquemin and Berry (1979).
} 
To test the argument that a higher degree of asset plasticity may increase the set of opportunities for reallocating those resources to other business opportunities with higher value creation prospects, and increasing the level of unrelated diversification (H3), we estimate the following regression model (e.g., Shyu and Chen 2009):

$$
\Delta U D_{i t}=\beta_{1} \Delta U D_{i t-1}+\beta_{2} \Delta \text { Performance }_{i t}+\beta_{3} \Delta \text { FinLev }_{i t}+\beta_{4} \Delta \text { Size }_{i t}+\beta_{5} \Delta \text { AssetPlasticity }_{i t}+\varepsilon_{i t}
$$

where $\Delta U D_{i t}$ denotes change in the firm's unrelated diversification levels; and $\Delta$ AssetPlasticity $_{i t}$ denotes change in the firm's degree of asset plasticity, with asset plasticity proxied by Tobin's $q$ ratio (as specified in Lang and Stulz 1994; Wernerfelt and Montgomery 1988; Lindenberg and Ross 1981). A higher Tobin's $q$ ratio implies that the market value of a firm's assets is higher than its replacement cost, i.e., the market perceives that a firm's assets are worth more than what it costs to replace them (Lindenberg and Ross 1981). Since an asset with a higher degree of plasticity may present a wide range of options in its reallocation to business opportunities with higher growth prospects, the market may value a 'plastic' asset more when compared to the cost of its replacement. Thus, a firm with higher asset plasticity may also have a higher Tobin's $q$ ratio. This reallocation of more 'plastic' assets may potentially help to increase sales in the subsidiaries to which they are relocated or 'shared', which also increases the unrelated level of diversification of a conglomerate.

To be consistent with hypothesis (3), the estimated coefficient of the change in levels of a firm's asset plasticity, $\beta_{5}$, should exhibit a positive sign for our sample of diversified firms.

\subsubsection{Endogeneity Problems}

Since diversification has an impact on performance, but performance also influences diversification decisions, as examined in several prior studies (e.g., Graham et al. 2002; Hyland and Diltz 2002; and Lang and Stulz 1994), we expect an endogenous relationship between the level of diversification and firm performance. Thus, an estimation method has to be selected in order to mitigate endogeneity (e.g., Kahn and Whited 2018). 
Panel data estimation using the Generalized Method of Moments (GMM) procedure, allows the dynamic nature of performance at firm level to be analyzed and controlled for endogeneity problems.

According to a non-negligible stream of the empirical literature, instrumental variables (IV) applied in GMM estimators may help to lessen endogeneity problems (e.g., Roberts and Whited 2013).

\section{Empirical Results}

\subsection{Univariate Statistics Analysis}

Table 2 presents sample characteristics in terms of data distribution by industry and country.

\section{[Insert Table 2 here]}

Panel A of table 2 shows that all major non-financial industries are represented in the sample, with an emphasis on manufacturing and trade.

Panel B presents the details of the distribution of the 2,396 diversified firms by country, for the sampling period. The distribution, by country, documented Italy, Spain and France as having the highest representations $(73.87$ percent of all the diversified firms in the sample), while Finland, Austria and Portugal exhibit the lowest representations (accounting for 8.51 percent of the total of sampled firms).

Table 3 reports the summary statistics for the variables used to test our hypotheses for the 2010-2017 sampling period.

\section{[Insert Table 3 here]}

To test for differences in means and medians of the variables included in the empirical model, we conducted parametric tests for the equality of means, and WilcoxonMann-Whitney tests for the equality of medians. Table 4 reports the means (on the left side) and medians (on the right side) of those variables, and statistics for equality tests across the sample. Section 1 and 2 compare the descriptive statistics, sorting the sample by unrelated diversified $v s$ related diversified firms and unlisted $v s$ listed diversified firms, respectively.

\section{[Insert Table 4 here]}


Testing for differences between the variables used to test our hypotheses in the unrelated diversified and related diversified firm subsamples for the 2010-2017 sampling period (section 1 of table 4), our results document that: (i) The means and medians of return on assets (Performance), financial leverage (FinLev), and return on equity (ROE), are not statistically different; (ii) Unrelated diversified firms exhibit statistically significant, at the 1 and 5 percent levels, higher asset tangibility (Tang), market-to-book (MtoB), plasticity of assets (AssetPlasticity) and risk index $(R I)$ than related diversified firms; (iii) Related diversified firms exhibit larger level of diversification $(L D)$ and size (Size) than unrelated diversified firms, with differences statistically significant at the 1 and 10 percent levels.

Means and medians of market-to-book $(M t o B)$ and risk index $(R I)$, are not statistically different when comparing unlisted and listed diversified firms. Unlisted diversified firms exhibit larger level of financial leverage (FinLev) than listed diversified firms, with differences statistically significant at the 5 percent level. Listed diversified firms exhibit a higher, and statistically significant at the 1 and 5 percent levels, return on assets (Performance), level of diversification $(L D)$, level of unrelated diversification $(U D)$, level of related diversification $(R D)$, size (Size), tangibility (Tang) and plasticity of assets (AssetPlasticity) than unlisted diversified firms (section 2 of table 4). Overall, all these findings are consistent with extant empirical literature (e.g. La Rocca et al. 2018; Wade and Gravill 2003; Chatterjee and Wernerfelt 1991; Bettis 1981).

Table 5 reports the Pearson correlation coefficients between the variables (scaled by the adjusted asset betas, for firms' specific financial leverage, as the accounting-based risk measure) used to estimate our hypotheses, showing that the correlation coefficients range from 0.0514 to 0.8146 in the subsidiaries' subsample, at the 1 percent level of statistical significance.

Scaling all the regressed variables by a risk index and using several explanatory variables simultaneously may raise multicollinearity problems among them, potentially yielding, e.g., less accurate estimators. To test for the existence of multicollinearity, we performed the variance inflation factor (VIF) test. The larger individual VIF is 9.16, and the mean VIF for our empirical models - $\mathrm{Eq}(1), \mathrm{Eq}(4), \operatorname{Eq}(5), \operatorname{Eq}(6.1)$ and $\operatorname{Eq}(6.2)$ - are 
respectively, $4.55,3.93,1.48,4.06$ and 3.42 , which are below the critical value of 10 , potentially revealing the non-existence of collinearity (Table 5).

\section{[Insert Table 5 here]}

\subsection{Regression Results}

Equation (1) tests the effect of the firm's overall diversification level on the firm's performance (H1). Equation (4) tests whether diversified firms exhibit a positive relationship between, both unrelated and related diversification levels, and their performance $(\mathrm{H} 2)$.

Table 6 reports the regression results on equation (1) and equation (4), for a sample of diversified firms, estimated using GMM estimators (Blundell and Bond 1998). We used the lag of all the right-hand-side variables and their first differences as instruments in our SYSGMM estimations.

\section{[Insert Table 6 here]}

The assumption of no serial correlation in the error terms was verified testing for the absence of a second-order serial correlation in residuals. In our models, this hypothesis of second-order serial correlation was always rejected.

The statistic for the Hansen test, for the null hypothesis of instruments that are uncorrelated with the disturbances and instruments that are valid, as well as the AR(2) test, suggested that our models, to test hypotheses $\mathrm{H} 1$ and $\mathrm{H} 2$, were valid, well-specified, and consistent. These test results are reported in the final two pairs of rows in table 6 .

Regression results document a statistically significant, at the 1 percent level, positive relationship between the firm's overall diversification level and the firm's performance. The SYS-GMM estimate is 0.004 percent, consistent with previous evidence in the literature (e.g., Giachetti 2012; Wan and Hoskisson 2003; Palich et al. 2000; Palepu 1985; Bettis 1981).

Findings from our regression analysis also show a dynamic pattern of performance, which is expressed through the positive coefficient of the lagged dependent variable, at the 1 percent level of statistical significance. Additionally, the negative and statistically significant, at the 1 percent level, coefficient of the financial leverage, and the positive and statistically significant, at the 1 percent level, coefficients of tangibility and growth 
opportunities are consistent with the findings of prior empirical research, e.g., La Rocca et al. (2018), Giachetti (2012), Chakrabarti et al. (2007), Wan and Hoskisson (2003).

In summary, these empirical results, document that diversified firms, arguably due to, among other factors, the potential operating and financial synergies, exhibit a positive relationship between overall diversification and their performance levels $\left(\beta_{2}\right)$, which is consistent with $\mathrm{H} 1$.

Since related diversification appears to be more related to positive operating synergies, and unrelated diversification more associated with positive financial synergies, the effect of both related and unrelated diversification levels should exhibit a positive sign $\left(\beta_{2}\right.$ and $\left.\beta_{3}\right)-\mathrm{H} 2$. Equation (4) tests the effect of both unrelated and related diversification levels on diversified firms' levels of performance.

Column (2) of table 6 reports the estimated coefficients $\left(\beta_{2}\right.$ and $\left.\beta_{3}\right)$ of the effects of unrelated and related diversification on diversified firms' performance $\left(U D_{i t}\right.$ and $\left.R D_{i t}\right)$. Regression results document positive relationships between unrelated ( 0.065 percent) and related (0.0098 percent) diversification levels and diversified firms' performance, as they are both statistically significant at the 1 percent level. Our results are consistent with $\mathrm{H} 2$ and with prior research, e.g., La Rocca et al. (2018), Bettis (1981).

Overall, these findings suggest that both operating and financial synergies, associated with related and unrelated diversification, respectively, may have an important and positive effect on a firm's performance level.

To test the argument that a higher degree of asset plasticity may increase the set of opportunities for reallocating those resources to other business opportunities with higher value creation prospects, and increasing the level of unrelated diversification, we estimated equation (5). To be consistent with H3, the estimated coefficient of the change in firms' levels of their asset plasticity, $\beta_{5}$, should exhibit a positive sign for our sample of diversified firms.

Findings from our regression analysis show a positive and statistically significant coefficient (0.0132 percent), at the 1 percent level, for the effect of change in firms' degrees of asset plasticity on change in their unrelated diversification levels. Table 7 reports the regression results on equation (5). 


\section{[Insert Table 7 here]}

Our results indicate that the change in firms' asset plasticity level exhibits a positive effect on the change in the level of unrelated diversification $\left(\beta_{5}\right)$, which is consistent with H3. These findings suggest that the higher the degree of asset 'plasticity', the larger the opportunity set for reallocating those assets to other business opportunities with higher value creation prospects and the greater the potential for increasing firm performance is through increasing unrelated diversification.

\section{Robustness Checks}

To test for robustness, we firstly adjusted asset betas for firms' financial leverage, using the book value of equity in Hamada's (1972) procedure. Secondly, we scaled all the variables by a 'risk index' adapted from Hannan and Hanweck (1988): $[R O A+(E / A)] / \sigma R O A$, where $R O A$ denotes the return on assets, $E / A$ the equity-total net assets ratio, and $\sigma_{R O A}$ the standard deviation of $R O A .^{31}$ Thirdly, we scaled all the variables by the coefficient of variation of the return on assets. Fourthly, we used the return on equity $(R O E)$, specified as the ratio of earnings before interest, tax, depreciation, and amortization (EBITDA) to equity, as a proxy for firm performance, following, e.g., Singh et al. (2007), Grant et al. (1988), Christensen and Montgomery (1981). Fifthly, we used the Tobin's $q$ ratio as a surrogate for growth opportunities, according to, e.g., Freund et al. (2007). Sixthly, to mitigate potential errors in our regression results, we included a variable to control for the non-included data concerning both foreign subsidiaries and subsidiaries without reported data on the database, such as, the number of foreign subsidiaries and subsidiaries without reported data per each diversified firm in our sample. Lastly, we used the number of subsidiaries per each diversified firm as a proxy for a firm total diversification level, following, e.g., George and Kabir (2012), Giachetti (2012), Wade and Gravill (2003), Denis et al. (2002).

\footnotetext{
${ }^{31}$ The risk index expresses, in units of the ROA standard deviation, how much the accounting earnings can fall before becoming negative, i.e, before a situation of accounting insolvency.
} 
As an additional check of robustness for $\mathrm{H} 1$ and $\mathrm{H} 2$, we tested the relationship between total, unrelated and related diversification levels and performance using a marketbased performance measure, estimating the following regression models:

$M t o B_{i t}=\beta_{1} L D_{i t}+\beta_{2}$ FinLev $_{i t}+\beta_{3}$ Size $_{i t}+\beta_{4}$ Tang $_{i t}+\varepsilon_{i t}$

and

$M t o B_{i t}=\beta_{1} U D_{i t}+\beta_{2} R D_{i t}+\beta_{3}$ FinLev $_{i t}+\beta_{4}$ Size $_{i t}+\beta_{5}$ Tang $_{i t}+\varepsilon_{i t}$

The regression results for the performed robustness checks, are reported in tables 8, 9, 10, 11 and 12. Column (1) of tables 8, 9, 10 and 12, and also column (3) of table 12, report, for the purpose of comparison, the estimated coefficients of the baseline models used to test our hypotheses H1, H2 and H3. Column (2) of tables 8, 9 and 10 reports the estimated coefficients of testing our hypotheses $\mathrm{H} 1, \mathrm{H} 2$ and $\mathrm{H} 3$, respectively, adjusting the risk index, asset betas, for firms' specific financial leverage, using $\mathrm{E}$ as the book value of equity in Hamada's (1972) procedure. Column (3) of tables 8, 9 and 10 reports the estimated coefficients of testing our hypotheses H1, H2 and H3, respectively, scaling all the variables by a RI adapted from Hannan and Hanweck (1988). Additionally, column (4) of tables 8, 9 and 10, and columns (2 and 4) of table 12, report the estimated coefficients of testing our hypotheses $\mathrm{H} 1, \mathrm{H} 2$ and $\mathrm{H} 3$, respectively, scaling all variables by the coefficient of variation of the return on assets. The regression results on $\mathrm{H} 1, \mathrm{H} 2$ and $\mathrm{H} 3$ hypotheses testing using the $R O E$ ratio as a proxy for firm performance are reported in column (5) of tables 8, 9 and 10, respectively. Column (6) of tables 8 and 9, displays the regression results estimated using Tobin's $q$ ratio as a surrogate for growth opportunities, on testing our hypotheses $\mathrm{H} 1$ and $\mathrm{H} 2$. The regression results on $\mathrm{H} 1$ and $\mathrm{H} 2$ hypotheses testing using a variable to control for the non-included data on both foreign subsidiaries and subsidiaries without reported data on the database are reported in column (7) of tables 8 and 9, respectively. Column (8) of table 8 reports the estimated coefficients of testing our hypotheses H1 using the number of subsidiaries per each diversified firm as a proxy for a firm total diversification level. These findings provide support for earlier results in terms of coefficient signs, magnitude, and statistical significance.

[Insert Tables 8 to 12 here] 
The finding of a positive relationship between a firm's total diversification level and a firm's performance $\left(\beta_{2}\right)$, holds for almost all the robustness checks performed and the estimation methods and empirical specifications used, reinforcing the baseline model results obtained for $\mathrm{H} 1$. When using the number of subsidiaries per each diversified firm as a proxy for a firm's total diversification level, our results also report a positive and statistically significant coefficient of the relationship between diversification level and performance.

The robustness check results document, considering all the alternative specifications of variables and estimation methods we used, a positive relationship between both unrelated and related diversification levels and diversified firms' performance, which are consistent with the results from $\mathrm{H} 2$ testing. However, it should be noted that in a few specifications, results were not statistically significant.

The results, on the robustness checks for $\mathrm{H} 3$, show a positive effect of the change in firms' asset plasticity level on the change in the unrelated diversification level, which are consistent with the baseline model results obtained for $\mathrm{H} 3$.

Regression results on equations 6.1 and 6.2, to check the robustness of results for H1 and $\mathrm{H} 2$ using a market-based performance measure, are reported in tables 11 and 12. The reported empirical findings suggest that firms' total diversification level exhibit a positive effect ( 0.3504 percent) on the market-based performance, statistically significate at the 1 percent level. Additionally, regression results also indicate that the unrelated and related diversification levels exhibit a positive effect on market-based performance, 0.5469 and 0.2394 percent, statistically significant at the 1 and 10 percent levels, respectively. These results strengthen the results obtained in the empirical testing of $\mathrm{H} 1$ and $\mathrm{H} 2$.

\section{Conclusions}

This paper carries out an empirical examination of the relationship between firms' total diversification levels, and also of both unrelated and related diversification levels, and the performance levels of diversified firms, using both accounting- and market-based performance measures. Additionally, we also test the argument that reallocating 'plastic' assets across different business units increases unrelated diversification. 
Regression results document that euro area diversified firms exhibit a positive and statistically significant relationship between their diversification level and performance, providing support to hypothesis 1 . Under the standard assumption that firms diversify with the aim of improving their overall economic performance and that the benefits of diversification outweigh the costs, our findings are consistent with that of a positive relationship between diversification and performance levels.

Regression results also show that sampled euro area diversified firms exhibit positive and statistically significant relationships, between unrelated and related diversification levels and diversified firms' performance. This evidence is consistent with the argument that horizontally diversified firms may have a positive relationship between financial synergies and performance, and vertically integrated diversified firms may exhibit a positive relationship between operating synergies and performance, both providing support for hypothesis 2 .

Empirical testing also provides evidence supporting the hypothesis that firms' overall, unrelated and related diversification levels exhibit a positive and statistically significant effect on the market-based performance. These empirical results are consistent with the prediction that the market-based performance measure (as well as the accountingbased performance measure) may be determined by firms' diversification behavior.

Empirical findings also support the argument that a higher degree of asset plasticity may increase the level of unrelated diversification, to potentially take advantage of an increase in the set of opportunities for reallocating those resources to other business opportunities with higher value creation prospects, consistent with hypothesis 3 . Regression results show a positive and statistically significant effect of change in firms' degrees of asset plasticity on the change in its unrelated diversification levels.

\section{References}

Adam, T., and V. Goyal. 2008. "The Investment Opportunity Set and Its Proxy Variables." Journal of Financial Research 31(1): 41-63.

Agarwal, S., M. Chiu, V. Souphom, and G. Yamashiro. 2011. "The Efficiency of Internal Capital Markets:

Evidence from The Annual Capital Expenditure Survey." Quarterly Review of Economics and Finance 51(2): 162-172. 
Ahn, S. 2011. “The Diversification Discount.” In The Art of Capital Restructuring, edited by H. K. Baker and H. Kiymaz.

Alchian, A. 1969. "Information Costs, Pricing, and Resource Unemployment.” Economic Inquiry 7(2): 109_ 128.

Alchian, A., and S. Woodward. 1987. "Reflections on the Theory of the Firm." Journal of Institutional and Theoretical Economics 143(1): 110-136.

Alchian, A., and S. Woodward. 1988. "The Firm Is Dead; Long Live the Firm a Review of Oliver E. Williamson's The Economic Institutions of Capitalism.” Journal of Economic Literature 26(1): 65-79.

Alexander, I., C. Mayer, and H. Weeds. 1996. Regulatory Structure and Risk and Infrastructure Firms: An International Comparison. World Bank Policy Research Working Paper, 1698.

Almeida, H., and D. Wolfenzon. 2006. "Should Business Groups be Dismantled? The Equilibrium Costs of Efficient Internal Capital Markets.” Journal of Financial Economics 79(1): 99-144.

Almeida, H., C. Kim, and H. Kim. 2015. "Internal Capital Markets in Business Groups: Evidence from the Asian Financial Crisis.” The Journal of Finance 70(6): 2539-2586.

Amihud, Y., and B. Lev. 1981. "Risk Reduction as a Managerial Motive for Conglomerate Mergers." Bell Journal of Economics 12(2): 605-617.

Anjos, F. 2010. "Costly Refocusing, the Diversification Discount, and the Pervasiveness of Diversified Firms." Journal of Corporate Finance 16(3): 276-287.

Bae, S., T. Kwon, and J. Lee. 2011. "Does Corporate Diversification by Business Groups Create Value? Evidence from Korean Chaebols.” Pacific-Basin Finance Journal 19(5): 535-553.

Bain, J. 1956. Barriers to New Competition. Cambridge: Harvard University Press.

Bain, J. 1959. Industrial Organization. New York: Wiley.

Beaver, W., and J. Manegold. 1975. "The Association between Market-Determined and AccountingDetermined Measures of Systematic Risk: Some Further Evidence." The Journal of Financial and Quantitative Analysis 10(2): 231-284.

Belenzon, S., T. Berkovitz, and L. Rios. 2013. "Capital Markets and Firm Organization: How Financial Development Shapes European Corporate Groups.” Management Science 59(6): 1326-1343.

Berger, P., and E. Ofek. 1995. "Diversification's Effect on Firm Value.” Journal of Financial Economics 37(1): 39-65.

Berger, P., and E. Ofek. 1999. "Causes and Effects of Corporate Refocusing Programs." The Review of Financial Studies 12(2): 311-345.

Bergh, D. 1997. "Predicting Divestiture of Unrelated Acquisitions: An Integrative Model of ex ante Conditions.” Strategic Management Journal 18(9): 715-731.

Berry, C. 1971. "Corporate Growth and Diversification.” The Journal of Law and Economics 14(2): 371-383.

Berry, C. 1974. "Corporate Diversification and Market Structure." The Bell Journal of Economics and Management Science 5(1): 196-204. 
Bettis, R. 1981. "Performance Differences in Related and Unrelated Diversified Firms." Strategic Management Journal 2(4): 379-393.

Bettis, R., and W. Hall. 1982. "Diversification Strategy, Accounting Determined Risk, and Accounting Determined Return.” Academy of Management Journal 25(2): 254-264.

Billett, M., and D. Mauer. 2000. "Diversification and the Value of Internal Capital Markets: The Case of Tracking Stock.” Journal of Banking and Finance 24(9): 1457-1490.

Billett, M., and D. Mauer. 2003. "Cross-Subsidies, External Financing Constraints, and the Contribution of the Internal Capital Market to Firm Value.” The Review of Financial Studies 16(4): 1167-1201.

Blundell, R., and S. Bond. 1998. "Initial Conditions and Moment Restrictions in Dynamic Panel Data Models." Journal of Econometrics 87(1): 115-143.

Bodnar, G., C. Tang, and J. Weintrop. 1997. "Both Sides of Corporate Diversification: The Value Impacts of Geographic and Industrial Diversification.” National Bureau of Economic Research Working Paper Series No. 6224.

Borda, A., J. Geleilate, W. Newburry, and S. Kundu. 2017. "Firm Internationalization, Business Group Diversification and Firm Performance: The Case of Latin American Firms.” Journal of Business Research 72: $104-113$.

Borghesi, R., J. Houston, and A. Naranjo. 2007. "Value, Survival, and the Evolution of Firm Organizational Structure." Financial Management 36(3): 5-31.

Buchuk, D., B. Larrain, F. Muñoz, and F. Urzúa I. 2014. “The Internal Capital Markets of Business Groups: Evidence from Intra-Group Loans.” Journal of Financial Economics 112(2): 190-212.

Campa, J., and S. Kedia. 2002. "Explaining the Diversification Discount." The Journal of Finance 57(4): 1731-1762.

Capar, N., and M. Kotabe. 2003. "The Relationship between International Diversification and Performance in Service Firms.” Journal of International Business Studies 34(4): 345-355.

Carney, M., E. Gedajlovic, P. Heugens, M. Essen, and J. Oosterhout. 2011. "Business Group Affiliation, Performance, Context, and Strategy: A Meta-analysis.” Academy of Management Journal 54(3): 437-460.

Carter, J. 1977. "In Search of Synergy: A Structure-Performance Test." The Review of Economics and Statistics 59(3): 279-289.

Caves, R., M. Porter, and A. Spence. 1980. Competition in an Open Economy: A Model Applied to Canada. Vol. 150, Harvard Economic Studies. Cambridge, MA: Harvard University Press.

Chakrabarti, A., K. Singh, and I. Mahmood. 2007. "Diversification and Performance: Evidence from East Asian Firms.” Strategic Management Journal 28(2): 101-120.

Chandler, A. 1962. Strategy and Structure: Chapters in the History of the Industrial Enterprise. Cambridge, MA: MIT Press.

Chatterjee, S., and B. Wernerfelt. 1991. "The Link Between Resources and Type of Diversification: Theory and Evidence." Strategic Management Journal 12(1): 33-48. 
Christensen, H., and C. Montgomery. 1981. "Corporate Economic Performance: Diversification Strategy Versus Market Structure.” Strategic Management Journal 2(4): 327-343.

Cleary, S. 1999. “The Relationship between Firm Investment and Financial Status.” The Journal of Finance 54(2): 673-692.

Cline, B., J. Garner, and A. Yore. 2014. "Exploitation of the Internal Capital Market and the Avoidance of Outside Monitoring." Journal of Corporate Finance 25: 234-250.

Coase, R. 1937. "The Nature of the Firm.” Economica 4(16): 386-405.

Çolak, G. 2010. "Diversification, Refocusing and Firm Value.” European Financial Management 16(3): 422448.

Custódio, C. 2014. "Mergers and Acquisitions Accounting and the Diversification Discount." The Journal of Finance 69(1): 219-240.

Datta, D., N. Rajagopalan, and A. Rasheed. 1991. "Diversification and Performance: Critical Review and Future Directions." Journal of Management Studies 28(5): 529-558.

de Andrés, P., G. Fuente, and P. Velasco. 2014. "Growth Opportunities and the Effect of Corporate Diversification on Value.” Spanish Review of Financial Economics 12(2): 72-81.

de Andrés, P., G. Fuente, and P. Velasco. 2016. “Are Real Options a Missing Piece in the DiversificationValue Puzzle?” International Review of Financial Analysis 48(1): 261-271.

de Andrés, P., G. Fuente, and P. Velasco. 2017. "Does It Really Matter How A Firm Diversifies? Assets-InPlace Diversification Versus Growth Options Diversification.” Journal of Corporate Finance 43(1): 316339.

Deloof, M. 1998. "Internal Capital Markets, Bank Borrowing, and Financing Constraints: Evidence from Belgian Firms.” Journal of Business Finance and Accounting 25(7-8): 945-968.

Demsetz, H. 1997. "The Firm in Economic Theory: A Quiet Revolution.” The American Economic Review 87(2): 426-429.

Denis, D., D. Denis, and A. Sarin. 1997. “Agency Problems, Equity Ownership, and Corporate Diversification." The Journal of Finance 52(1): 135-160.

Denis, D., D. Denis, and K. Yost. 2002. "Global Diversification, Industrial Diversification, and Firm Value." The Journal of Finance 57(5): 1951-1979.

Devos, E., P. Kadapakkam, and S. Krishnamurthy. 2008. "How Do Mergers Create Value? A Comparison of Taxes, Market Power, and Efficiency Improvements as Explanations for Synergies." The Review of Financial Studies 22(3): 1179-1211.

Dewaelheyns, N., and C. Van Hulle. 2012. "Capital Structure Adjustments in Private Business Group Companies." Applied Financial Economics 22(15): 1275-1288.

Dittmar, A., and A. Shivdasani. 2003. "Divestitures and Divisional Investment Policies.” The Journal of Finance 58(6): 2711-2744. 
Erdorf, S., T. Hartmann-Wendels, N. Heinrichs, and M. Matz. 2013. "Corporate Diversification and Firm Value: A Survey of Recent Literature" Financial Markets and Portfolio Management 27(2): 187-215.

Erickson, T., and T. Whited. 2000. "Measurement Error and the Relationship between Investment and q." Journal of Political Economy 108(5): 1027-1057.

Faccio, M., and L. Lang. 2002. "The Ultimate Ownership of Western European Corporations.” Journal of Financial Economics 65(3): 365-395.

Fama, E. 1970. "Efficient Capital Markets: A Review of Theory and Empirical Work." The Journal of Finance 25(2): 383-417.

Fama, E., and K. French. 1997. "Industry Costs of Equity." Journal of Financial Economics 43(2): 153-193.

Fang, Y., M. Wade, A. Delios, and P. Beamish. 2007. "International Diversification, Subsidiary Performance, and the Mobility of Knowledge Resources.” Strategic Management Journal 28(10): 1053-1064.

Farjoun, M. 1998. "The Independent and Joint Effects of the Skill and Physical Bases of Relatedness in Diversification." Strategic Management Journal 19(7): 611-630.

Fauver, L., J. Houston, and A. Naranjo. 2003. “Capital Market Development, International Integration, Legal Systems, and the Value of Corporate Diversification: A Cross-Country Analysis.” Journal of Financial and Quantitative Analysis 38(1): 135-158.

Ferris, S., K. Kim, and P. Kitsabunnarat. 2003. "The Costs (and Benefits?) of Diversified Business Groups: The Case of Korean Chaebols.” Journal of Banking and Finance 27(2): 251-273.

Ferris, S., N. Sen, C. Lim, and G. Yeo. 2002. "Corporate Focus versus Diversification: The Role of Growth Opportunities and Cashflow.” Journal of International Financial Markets, Institutions and Money 12(3): $231-252$.

Franke, G. 1987. "Reflections on the Theory of the Firm: Comment." Journal of Institutional and Theoretical Economics 143(1): 143-148.

Freund, S., E. Trahan, and G. Vasudevan. 2007. "Effects of Global and Industrial Diversification on Firm Value and Operating Performance.” Financial Management 36(4): 143-161.

Gabriel, S., and C. Baker. 1980. "Concepts of Business and Financial Risk." American Journal of Agricultural Economics 62(3): 560-564.

Gatzer, S., D. Hoang, and M. Ruckes. 2014. Internal Capital Markets and Diversified Firms: Theory and Practice. Working Paper Series in Economics, 64. Karlsruher Institut für Technologie (KIT).

Gaur, A., and V. Kumar. 2009. "International Diversification, Business Group Affiliation and Firm Performance: Empirical Evidence from India.” British Journal of Management 20(2): 172-186.

George, R., and R. Kabir. 2012. "Heterogeneity in Business Groups and the Corporate Diversification-Firm Performance Relationship.” Journal of Business Research 65(3): 412-420.

George, R., R. Kabir, and J. Qian. 2011. "Investment-Cash Flow Sensitivity and Financing Constraints: New Evidence from Indian Business Group Firms.” Journal of Multinational Financial Management 21(2): $69-88$. 
Gertner, R., and D. Scharfstein. 2013. "Internal Capital Markets.” In Handbook of Organizational Economics, edited by R. Gibbons, and J. Roberts, chapter 16: 655-697. Princeton, NJ, USA: Princeton University Press.

Gertner, R., D. Scharfstein, and J. Stein. 1994. “Internal Versus External Capital Markets.” Quarterly Journal of Economics 109(4): 1211-1230.

Gertner, R., E. Powers, and D. Scharfstein. 2002. "Learning about Internal Capital Markets from Corporate Spin-offs." The Journal of Finance 57(6): 2479-2506.

Giachetti, C. 2012. “A Resource-Based Perspective on the Relationship Between Service Diversification and Firm Performance: Evidence from Italian Facility Management Firms.” Journal of Business Economics and Management 13(3): 567-585.

Glaser, M., F. Lopez-de-Silanes, and Z. Sautner. 2013. "Opening the Black Box: Internal Capital Markets and Managerial Power.” The Journal of Finance 68(4): 1577-1631.

Gomes, J., and D. Livdan. 2004. “Optimal Diversification: Reconciling Theory and Evidence.” The Journal of Finance 59(2): 507-535.

Gonenc, H., O. Kan, and E. Karadagli. 2007. "Business Groups and Internal Capital Markets.” Emerging Markets Finance and Trade 43(2): 63-81.

Gossy, G. 2008. A Stakeholder Rationale for Risk Management: Implications for Corporate Finance Decisions, 1st Edition. Germany: Gabler Edition Wissenschaft.

Goudie, A., and G. Meeks. 1982. "Diversification by Merger.” Economica 49(196): 447-459.

Graham, J., M. Lemmon, and J. Wolf. 2002. “Does Corporate Diversification Destroy Value?" The Journal of Finance 57(2): 695-720.

Grant, R. 2016. Contemporary Strategy Analysis: Text and Cases Edition, 9th Edition. United Kingdom: John Wiley \& Sons.

Grant, R., A. Jammine, and H. Thomas. 1988. "Diversity, Diversification, and Profitability among British Manufacturing Companies, 1972-84.” Academy of Management Journal 31(4): 771-801.

Grant, R., and A. Jammine. 1988. "Performance Differences Between the Wrigley/Rumelt Strategic Categories.” Strategic Management Journal 9(4): 333-346.

Greening, T. 1980. "Diversification, Strategic Groups and the Structure-Conduct- Performance Relationship: A Synthesis." The Review of Economics and Statistics 62(3): 475-477.

Gugler, K., E. Peev, and E. Segalla. 2013. “The Internal Workings of Internal Capital Markets: Cross-Country Evidence." Journal of Corporate Finance 20: 59-73.

Hamada, R. 1972. "The Effect of the Firm's Capital Structure on the Systematic Risk of Common Stocks." The Journal of Finance 27(2): 435-452.

Hann, N., M. Ogneva, and O. Ozbas. 2013. "Corporate Diversification and the Cost of Capital.” The Journal of Finance 68(5): 1961-1999. 
Hannan, T., and G. Hanweck. 1988. "Bank Insolvency Risk and the Market for Large Certificates of Deposit.” Journal of Money, Credit and Banking 20(2): 203-211.

Hansen, G., and B. Wernerfelt. 1989. "Determinants of Firm Performance: The Relative Importance of Economic and Organizational Factors.” Strategic Management Journal 10(5): 399-411.

Hart, O., and B. Holmström. 2010. “A Theory of Firm Scope.” Quarterly Journal of Economics 125(2): 483513.

Hart, O., and J. Moore. 1990. "Property Rights and the Nature of the Firm." Journal of Political Economy 98(6): 1119-1158.

He, Z., and L. Kryzanowski. 2007. "Cost of equity for Canadian and U.S. sectors." The North American Journal of Economics and Finance 18(2): 215-229.

Hitt, M., L. Bierman, K. Uhlenbruck, and K. Shimizu. 2006. "The Importance of Resources in the Internationalization of Professional Service Firms: The Good, the Bad, and the Ugly." Academy of Management Journal 49(6): 1137-1157.

Hitt, M., R. Hoskisson, and H. Kim. 1997. "International Diversification: Effects on Innovation and Firm Performance in Product-Diversified Firms.” Academy of Management Journal 40(4): 767-798.

Hoshi, T., A. Kashyap, and D. Scharfstein. 1991. "Corporate Structure, Liquidity, and Investment: Evidence from Japanese Industrial Groups.” The Quarterly Journal of Economics 106(1): 33-60.

Hoskisson, R. 1987. "Multidivisional Structure and Performance: The Diversification Strategy Contingency." Academy of Management Proceedings 30(4): 625-644.

Hoskisson, R. and M. Hitt. 1994. Downscoping: How to Tame the Diversified Firm. New York: Oxford University Press.

Hoskisson, R., and R. Johnson. 1992. "Research Notes and Communications Corporate Restructuring and Strategic Change: The Effect on Diversification Strategy and R\&D Intensity." Strategic Management Journal 13(8): 625-634.

Hund, J., D. Monk, and S. Tice. 2012. Apples to Apples: The Economic Benefit of Corporate Diversification. http://ssrn.com/abstract=2023786.

Hund, J., D. Monk, and S. Tice. 2019. “A Manufactured Diversification Discount.” Critical Finance Review (forthcoming).

Hyland, D., and J. Diltz. 2002. "Why Firms Diversify: An Empirical Examination.” Financial Management 31(1): 51-81.

Inderst, R., and C. Laux. 2005. "Incentives in Internal Capital Markets: Capital Constraints, Competition, and Investment Opportunities.” RAND Journal of Economics 36(1): 215-228.

Jacquemin, A., and C. Berry. 1979. "Entropy Measure of Diversification and Corporate Growth.” The Journal of Industrial Economics 27(4): 359-369.

Jensen, M. 1986. "Agency Cost of Free Cash Flow, Corporate Finance, and Takeovers." The American Economic Review 76(2): 323-329. 
Jia, N, J. Shi, and Y. Wang. 2013. "Coinsurance Within Business Groups: Evidence from Related Party Transactions in an Emerging Market.” Management Science 59(10): 2295-2313.

Kahn, R., and T. Whited. 2018. "Identification Is Not Causality, and Vice Versa." The Review of Corporate Finance Studies 7(1): 1-21.

Kale, J., T. Noe, and G. Ramirez. 1991. "The Effect of Business Risk on Corporate Capital Structure: Theory and Evidence." The Journal of Finance 46(5): 1693-1715.

Kaplan, P., and J. Peterson. 1998. "Full-Information Industry Betas.” Financial Management 27(2): 85-93.

Khanna, N., and S. Tice. 2001. "The Bright Side of Internal Capital Markets.” The Journal of Finance 56(4): 1489-1528.

Khanna, T., and J. Rivkin. 2001. "Estimating the Performance Effects of Business Groups in Emerging Markets." Strategic Management Journal 22(1): 45-74.

Khanna, T., and K. Palepu. 2000. "Is Group Affiliation Profitable in Emerging Markets? An Analysis of Diversified Indian Business Groups.” The Journal of Finance 55(2): 867-891.

Kim, H., and H. Kung. 2017. “The Asset Redeployability Channel: How Uncertainty Affects Corporate Investment." The Review of Financial Studies 30(1): 245-280.

Kim, E., and J. McConnell. 1977. "Corporate Mergers and the Co-Insurance of Corporate Debt.” The Journal of Finance 32(2): 349-365.

Kim, E., and V. Singal. 1993. "Mergers and Market Power: Evidence from the Airline Industry." The American Economic Review 83(3): 549-69.

Kim, H., R. Hoskisson, and W. Wan. 2004. "Power Dependence, Diversification Strategy, and Performance in Keiretsu Member Firms.” Strategic Management Journal 25(7): 613-636.

Kim, W., P. Hwang, and W. Burgers. 1993. "Multinationals' Diversification and the Risk-Return Trade-Off." Strategic Management Journal 14(4): 275-286.

Kor, Y., and H. Leblebici. 2005. "How Do Interdependencies Among Human-Capital Deployment, Development, and Diversification Strategies Affect Firms' Financial Performance?" Strategic Management Journal 26(10): 967-985.

La Rocca, M., T. La Rocca, and F. Vidal. 2018. "Multibusiness Firms and Performance in Italy. What Role Does Relatedness Play?” European Research on Management and Business Economics 24(2): 63-70.

La Rocca, M., T. La Rocca, D. Gerace, and C. Smark. 2009. "Effect of Diversification on Capital Structure.” Accounting and Finance 49(4): 799-826.

Lafontaine, F., and M. Slade. 2007. "Vertical Integration and Firm Boundaries: The Evidence." Journal of Economic Literature 45(3): 629-685.

Lamont, O. 1997. "Cash Flow and Investment: Evidence from Internal Capital Markets." The Journal of Finance 52(1): 83-109.

Lang, L., and R. Stulz. 1994. “Tobin's Q, Corporate Diversification, and Firm Performance.” Journal of Political Economy 102(6): 1248-1280. 
Lecraw, D. 1984. "Diversification Strategy and Performance." The Journal of Industrial Economics 33(2): $179-198$.

Lee, A., J. Lee, and C. Lee. 2009. Financial Analysis, Planning \& Forecasting, Theory and Application. 2nd Edition. Singapore: World Scientific Publishing.

Lee, D., and K. Lee. 2002. "The Dark Side of Internal Capital Allocation: The Case of Korean Chaebols." Seoul Journal of Economics 15(2): 321-368.

Leland, H. 2007. "Financial Synergies and the Optimal Scope of the Firm: Implications for Mergers, Spinoffs, and Structured Finance." The Journal of Finance 62(2): 765-807.

Lev, B., and T. Sougiannis. 1999. "Penetrating the Book-to-Market Black Box: The R\&D Effect.” Journal of Business Finance and Accounting 26(3 4): 419-449.

Lewellen, W. 1971. "A Pure Financial Rationale for the Conglomerate Merger." The Journal of Finance 26(2): 521-537.

Liebeskind, J. 2000. "Internal Capital Markets: Benefits, Costs, and Organizational Arrangements." Organization Science 11(1): 58-76.

Lindenberg, E., and S. Ross. 1981. "Tobin's q Ratio and Industrial Organization.” Journal of Business 54(1): $1-32$.

Lins, K., and H. Servaes. 1999. "International Evidence on the Value of Corporate Diversification." The Journal of Finance 54(6): 2215-2239.

Lu, J., and P. Beamish. 2004. "International Diversification and Firm Performance: The S-Curve Hypothesis." Academy of Management Journal 47(4): 598-609.

Luffman, G., and R. Reed. 1984. The Strategy \& Performance of British Industry, 1970-80. London: Macmillan.

Maksimovic, V., and G. Phillips. 2002. "Do Conglomerate Firms Allocate Resources Inefficiently Across Industries? Theory and Evidence.” The Journal of Finance 57(2): 721-767.

Maksimovic, V., and G. Phillips. 2007. “Conglomerate Firms and Internal Capital Markets.” In Handbook of Corporate Finance, edited by B. Espen Eckbo, vol. 1, chapter 8: 423-477. Elsevier/North-Holland.

Maksimovic, V., and G. Phillips. 2013. "Conglomerate Firms, Internal Capital Markets, and the Theory of the Firm.” Annual Review of Financial Economics 5: 225-244.

Manne, H. 1965. "Mergers and the Market for Corporate Control.” Journal of Political Economy 73(2): 110120.

Markides, C. 1992. "Consequences of Corporate Refocusing: Ex Ante Evidence.” Academy of Management Journal 35(2): 398-412.

Markides, C. 1995. "Diversification, Restructuring and Economic Performance." Strategic Management Journal 16(2): 101-118.

Markides, C., and P. Williamson. 1994. "Related Diversification, Core Competences and Corporate Performance." Strategic Management Journal 15: 149-165. 
Marschak, J. 1938. "Money and the Theory of Assets." Econometrica 6(4): 311-325.

Martin, J., and A. Sayrak. 2003. "Corporate Diversification and Shareholder Value: A Survey of Recent Literature." Journal of Corporate Finance 9(1): 37-57.

Matsusaka, J., and V. Nanda. 2002. “Internal Capital Markets and Corporate Refocusing." Journal of Financial Intermediation 11(2): 176-211.

Menéndez-Alonso, E. 2003. "Does Diversification Strategy Matter in Explaining Capital Structure? Some Evidence from Spain.” Applied Financial Economics 13(6): 427-430.

Meyer, M., P. Milgrom, and J. Roberts. 1992. “Organizational Prospects, Influence Costs, and Ownership Changes.” Journal of Economics and Management Strategy 1(1): 9-35.

Michel, A., and I. Shaked. 1984. "Does Business Diversification Affect Performance?" Financial Management 13(4): 18-25.

Milgrom, P., and J. Roberts. 1992. Economics, Organization, and Management. New Jersey, USA: Prentice Hall.

Montgomery, C. 1982. "The Measurement of Firm Diversification: Some New Empirical Evidence." Academy of Management Journal 25(2): 299-307.

Montgomery, C. 1985. "Product-Market Diversification and Market Power." Academy of Management Journal 28(4): 789-798.

Montgomery, C. 1994. “Corporate Diversification.” Journal of Economic Perspectives 8(3): 163-178.

Montgomery, C., and B. Wernerfelt. 1988. "Diversification, Ricardian Rents, and Tobin's q." The RAND Journal of Economics 19(4): 623-632.

Morin, R., and S. Jarrell. 2000. Driving Shareholder Value: Value-Building Techniques for Creating Shareholder Value. New York, USA: McGraw-Hill.

Mueller, D. 1977. "The Effects of Conglomerate Mergers: A Survey of the Empirical Evidence.” Journal of Banking and Finance 1(4): 315-347.

Mullainathan, S. and D. Scharfstein. 2001. "Do Firm Boundaries Matter?” The American Economic Review 91(2): 195-199.

Ozbas, O., and D. Scharfstein. 2010. "Evidence on the Dark Side of Internal Capital Markets." Review of Financial Studies 23(2): 581-599.

Palepu, K. 1985. "Diversification Strategy, Profit Performance and the Entropy Measure." Strategic Management Journal 6(3): 239-255.

Palich, L., L. Cardinal, and C. Miller. 2000. "Curvilinearity in the Diversification-Performance Linkage: An Examination of over Three Decades of Research.” Strategic Management Journal 21: 155-174.

Pandya, A., and N. Rao. 1998. "Diversification and Firm Performance: An Empirical Evaluation.” Journal of Financial and Strategic Decisions 11(2): 67-81.

Penrose, E. 1959. The Theory of the Growth of the Firm. New York: John Wiley. 
Pomfret, R., and D. Shapiro. 1980. "Firm Size, Diversification, and Profitability of Large Corporations in Canada." Journal of Economic Studies 7(3): 140-150.

Porter, M. 1979. "The Structure Within Industries and Companies' Performance." Review of Economics and Statistics 61(2): 214-227.

Porter, M. 1980. Competitive Strategy. New York: Free Press.

Porter, M. 1981. "The Contributions of Industrial Organization to Strategic Management." The Academy of Management Review 6(4): 609-620.

Porter, M. 1989. "How Competitive Forces Shape Strategy." In Readings in Strategic Management, edited by D. Asch and C. Bowman: 133-143. London: Macmillan Education UK.

Rajan, R., and L. Zingales. 1998. "Financial Dependence and Growth." The American Economic Review 88(3): 559-586.

Rajan, R., H. Servaes, and L. Zingales. 2000. "The Cost of Diversity: The Diversification Discount and Inefficient Investment.” The Journal of Finance 55(1): 35-80.

Ramanujam, V., and P. Varadarajan. 1989. “Research on Corporate Diversification: A Synthesis.” Strategic Management Journal 10(6): 523-551.

Riahi-Belkaoui, A. 1996. "Internationalization, Diversification Strategy and Ownership Structure: Implications for French MNE Performance.” International Business Review 5(4): 367-376.

Roberts, M., and T. Whited. 2013. "Endogeneity in Empirical Corporate Finance." In Handbook of the Economics of Finance, edited by G. Constantinides, M. Harris and R. Stulz, vol. 2A, chapter 7: 493-572. Elsevier.

Rumelt, R. 1974. Strategy, Structure and Economic Performance. Cambridge, MA: Harvard University Press. Santioni, R., F. Schiantarelli, and F. Strahan. 2017. "Internal Capital Markets in Times of Crisis: The Benefit of Group Affiliation in Italy.” National Bureau of Economic Research Working Paper Series. No. 23541.

Sapienza, P. 2001. “The Bright Side of Internal Capital Markets: Discussion.” The Journal of Finance 56(4): 1528-1531.

Sapienza, P. 2002. "The Effects of Banking Mergers on Loan Contracts." The Journal of Finance 57(1): 32968.

Sautner, Z., and B. Villalonga. 2010. "Corporate Governance and Internal Capital Markets." Harvard Business School Finance Working Paper. No. 1530565.

Scharfstein, D., and J. Stein. 2000. "The Dark Side of Internal Capital Markets: Divisional Rent-Seeking and Inefficient Investment.” The Journal of Finance 55(6): 2537-2564.

Scherer, F. 1980. Industrial Market Structure and Economic Performance. 2nd Edition. Boston, MA: Houghton Mifflin.

Scherer, F., and D. Ross. 1990. Industrial Market Structure and Economic Performance. Boston: Houghton Mifflin Company.

Schmalensee, R. 1985. “Do Markets Differ Much?” The American Economic Review 75(3): 341-351. 
Schumpeter, J. 1942. Capitalism, Socialism, and Democracy. London and New York: Harper \& Brothers.

Scott, K. 1987. "Reflections on the Theory of the Firm: Comment." Journal of Institutional and Theoretical Economics 143(1): 137-142.

Seru, A. 2014. "Firm Boundaries Matter: Evidence from Conglomerates and R\&D Activity." Journal of Financial Economics 111(2): 381-405.

Servaes, H. 1996. "The Value of Diversification During the Conglomerate Merger Wave." The Journal of Finance 51(4): 1201-1225.

Shin, H., and R. Stulz. 1998. “Are Internal Capital Markets Efficient?” The Quarterly Journal of Economics 113(2): 531-552.

Shleifer, A., and R. Vishny. 1992. "Liquidation Values and Debt Capacity: A Market Equilibrium Approach." The Journal of Finance 47(4): 1343-1366.

Shyu, J., and Y. Chen. 2009. "Diversification, Performance, and the Corporate Life Cycle." Emerging Markets Finance and Trade 45(6): 57-68.

Singh, M., A. Nejadmalayeri, and I. Mathur. 2007. "Performance Impact of Business Group Affiliation: An Analysis of the Diversification-Performance Link in a Developing Economy." Journal of Business Research 60(4): 339-347.

Stein, J. 2003. “Agency, Information and Corporate Investment.” In Handbook of the Economics of Finance, edited by G. Constantinides, M. Harris, and R. Stulz, Vol. 1: 111-165. Elsevier.

Steiner, T. 1997. "The Corporate Sell-Off Decision of Diversified Firms.” Journal of Financial Research 20(2): 231-241.

Stimpert, J., and I. Duhaime. 1997. "Seeing the Big Picture: The Influence of Industry, Diversification, and Business Strategy on Performance.” Academy of Management Journal 40(3): 560-583.

Tallman, S., and J. Li. 1996. "Effects of International Diversity and Product Diversity on the Performance of Multinational Firms.” Academy of Management Journal 39(1): 179-196.

Teece, D. 1980. "Economies of Scope and the Scope of the Enterprise." Journal of Economic Behavior and Organization 1(3): 223-247.

Teece, D. 1984. "Economic Analysis and Strategic Management.” California Management Review 26(3): 87110.

Teece, D., G. Pisano, and A. Shuen. 1997. "Dynamic Capabilities and Strategic Management." Strategic Management Journal 18(7): 509-533.

Thakor, A. 1993. “Corporate Investments and Finance.” Financial Management 22(2): 135-144.

Thomas, D. 2006. "International Diversification and Firm Performance in Mexican Firms: A Curvilinear Relationship?” Journal of Business Research 59(4): 501-507.

Tong, Z. 2012. “Coinsurance Effect and Bank Lines of Credit.” Journal of Banking and Finance 36(6): 15921603. 
Utton, M. 1977. "Large Firm Diversification in British Manufacturing Industry." The Economic Journal 87(345): 96-113.

Varadarajan, P., and V. Ramanujam. 1987. "Diversification and Performance: A Reexamination Using a New Two-Dimensional Conceptualization of Diversity in Firms.” Academy of Management Journal 30(2): 380-393.

Villalonga, B. 2003. Research Roundtable Discussion: The Diversification Discount. Social Science Research Network working paper. http://ssrn.com/abstract=402220.

Villalonga, B. 2004a. "Diversification Discount or Premium? New Evidence from the Business Information Tracking Series." The Journal of Finance 59(2): 479-506.

Villalonga, B. 2004b. "Does Diversification Cause the "Diversification Discount”?" Financial Management 33(2): 5-27.

Wade, M., and J. Gravill. 2003. "Diversification and Performance of Japanese IT Subsidiaries: A ResourceBased View." Information and Management 40(4): 305-316.

Walker, P. 2017. The Theory of the Firm: An Overview of the Economic Mainstream. New York: Routledge.

Wan, W., and R. Hoskisson. 2003. "Home Country Environments, Corporate Diversification Strategies, and Firm Performance.” Academy of Management Journal 46(1): 27-45.

Wang, C., and P. Ahmed. 2007. "Dynamic Capabilities: A Review and Research Agenda." International Journal of Management Reviews 9(1): 31-51.

Wei, K., and Y. Zhang. 2008. “Ownership Structure, Cash Flow, and Capital Investment: Evidence from East Asian Economies before the Financial Crisis.” Journal of Corporate Finance 14(2): 118-132.

Wernerfelt, B. 1984. “A Resource-Based View of the Firm.” Strategic Management Journal 5(2): 171-180.

Wernerfelt, B., and C. Montgomery. 1988. "Tobin's q and the Importance of Focus in Firm Performance." The American Economic Review 78(1): 246-250.

Whited, T. 2001. "Is It Inefficient Investment That Causes the Diversification Discount?" The Journal of Finance 56(5): 1667-1691.

Williamson, O. 1975. Markets and Hierarchies: Analysis and Antitrust Implications. New York: The Free Press, Macmillan Publishers.

Williamson, O. 1985. The Economic Institutions of Capitalism: Firms, Markets, Relational Contracting. New York: The Free Press, Macmillan Publishers.

Williamson, O. 1988. “Corporate Finance and Corporate Governance.” The Journal of Finance 43(3): 567591.

Wulf, J. 2009. "Influence and Inefficiency in the Internal Capital Market." Journal of Economic Behavior and Organization 72(1): 305-321.

Yan, A. 2006. "Value of Conglomerates and Capital Market Conditions." Financial Management 35(4): 530 . 
Tables

Table 1. Variables specification, and expected and estimated variable coefficient signs

\begin{tabular}{|c|c|c|c|}
\hline Variables & Specification & $\begin{array}{l}\text { Expected } \\
\text { Sign }\end{array}$ & $\begin{array}{l}\text { Estimated } \\
\text { Sign }\end{array}$ \\
\hline \multicolumn{4}{|l|}{ Dependent } \\
\hline $\begin{array}{l}\text { Performance: Return on Assets } \\
\text { (ROA) }\end{array}$ & $\begin{array}{l}\text { Ratio of earnings before interest, tax, depreciation, } \\
\text { and amortization (EBITDA) to total net assets } \\
\text { (e.g., La Rocca et al. 2018; George and Kabir } \\
\text { 2012; Chakrabarti et al. 2007; Singh et al. 2007; } \\
\text { Kim et al. 2004; Khanna and Palepu 2000). }\end{array}$ & & \\
\hline \multicolumn{4}{|l|}{ Independent } \\
\hline Firm diversification level ( $L D)$ & $\begin{array}{l}\text { Total entropy diversification index as in Palepu } \\
\text { (1985) and Jacquemin and Berry (1979). }\end{array}$ & + & + \\
\hline Related diversification level ( $R D)$ & $\begin{array}{l}\text { Related diversification index, as specified in } \\
\text { Palepu (1985), Jacquemin and Berry (1979). }\end{array}$ & + & + \\
\hline $\begin{array}{l}\text { Unrelated diversification level } \\
\text { (UD) }\end{array}$ & $\begin{array}{l}\text { Unrelated diversification index, as specified in } \\
\text { Palepu (1985), Jacquemin and Berry (1979). }\end{array}$ & + & + \\
\hline Financial leverage (FinLev) & $\begin{array}{l}\text { Ratio of long-term debt plus short-term loans to } \\
\text { total net assets (e.g., La Rocca et al. 2018; George } \\
\text { and Kabir 2012; Giachetti 2012; Muñoz-Bullón } \\
\text { and Sánchez-Bueno 2012; Lu and Beamish 2004). }\end{array}$ & $-/+$ & - \\
\hline $\begin{array}{l}\text { Size (Size) and Tangibility of } \\
\text { assets (Tang) }\end{array}$ & $\begin{array}{l}\text { Natural logarithm of total net assets, and ratio of } \\
\text { tangible fixed assets to total net assets, } \\
\text { respectively. }\end{array}$ & + & $-a^{a}$ \\
\hline Growth opportunities (MtoB) & $\begin{array}{l}\text { Market-to-book ratio as the equity market value to } \\
\text { its book value both in time } \mathrm{t} \text { (e.g., George et al. } \\
\text { 2011; Adam and Goyal 2008; Wei and Zhang } \\
\text { 2008; Lev and Sougiannis 1999; Hoshi et al. } \\
\text { 1991). }\end{array}$ & + & + \\
\hline Asset Plasticity (AssetPlasticity) & $\begin{array}{l}\text { Proxied by Tobin's } q \text { ratio, as specified in Lang } \\
\text { and Stulz (1994), Wernerfelt and Montgomery } \\
\text { (1988), and Lindenberg and Ross (1981). }\end{array}$ & + & + \\
\hline
\end{tabular}

Note: ${ }^{a}$ Coefficient sign partially not statistically significant

Table 2. Characteristics of the sample

The industry classification was based on the NACE Rev. 2's main section and is according to the aggregation of Fama and French's (1997) industry classification presented by Dewaelheyns and Van Hulle (2012).

\begin{tabular}{lcc}
\hline Panel A: Industry composition & Number of firms in sample & $\%$ \\
\hline Industry & & $4.63 \%$ \\
\hline $\begin{array}{l}\text { Agriculture, forestry and fishing; Mining and quarrying; Electricity, gas, steam and air } \\
\text { conditioning supply; Water supply; sewerage, waste management and remediation } \\
\text { activities (Industry 1) }\end{array}$ & 111 & $39.77 \%$ \\
Manufacturing (Industry 2) & 953 & $5.26 \%$ \\
Construction (Industry 3) & 126 & $21.62 \%$ \\
Trade (Wholesale and Retail) (Industry 4) & 518 &
\end{tabular}



activities; Arts, entertainment and recreation; Other service activities) (Industry 6)

Panel B: Country composition

\begin{tabular}{lcc}
\hline \multicolumn{1}{c}{ Country } & Number of firms in sample & $\%$ \\
\hline Austria & 39 & $1.63 \%$ \\
Belgium & 176 & $7.35 \%$ \\
Finland & 130 & $5.43 \%$ \\
France & 432 & $18.03 \%$ \\
Germany & 246 & $10.27 \%$ \\
Italy & 836 & $34.89 \%$ \\
Portugal & 35 & $1.45 \%$ \\
Spain & 502 & $20.95 \%$ \\
& 2396 &
\end{tabular}

Table 3. Summary statistics of the variables used to test our hypotheses

The diversified firms' sample consists of 19,168 firm-year observations from the 2010 to 2017 Amadeus files. This table reports the number of observations $(\mathrm{N})$, mean, median, standard deviation (Std. Dev.), coefficient of variation (cv), minimum (Min), maximum (Max) of the variables considered in the empirical applications to test hypotheses. The variables used to test hypotheses were described in detail in subsection 3.2 and in table 1 .

\begin{tabular}{|c|c|c|c|c|c|c|c|}
\hline Variables & $\mathrm{N}$ & Mean & Median & Std. Dev. & $\mathrm{CV}$ & Min & Max \\
\hline Performance $_{i t}$ & 18769 & 0.10505 & 0.09466 & 0.06458 & 0.61479 & -0.18144 & 0.77319 \\
\hline$L D_{i t}$ & 19164 & 0.80529 & 0.69100 & 0.57028 & 0.70817 & 0.00000 & 3.68681 \\
\hline$U D_{i t}$ & 19164 & 0.42782 & 0.37786 & 0.39290 & 0.91838 & 0.00000 & 2.17244 \\
\hline$R D_{i t}$ & 19164 & 0.37747 & 0.22826 & 0.44785 & 1.18645 & 0.00000 & 2.99603 \\
\hline FinLev $_{i t}$ & 18878 & 0.23852 & 0.22554 & 0.16332 & 0.68471 & 0.00000 & 0.99874 \\
\hline Size $_{i t}$ & 18878 & 11.71462 & 11.47015 & 1.60741 & 0.13721 & 2.70805 & 19.86097 \\
\hline Tang $_{i t}$ & 18811 & 0.23358 & 0.19604 & 0.18467 & 0.79061 & 0.00000 & 0.97403 \\
\hline$M$ to $B_{i t}$ & 13337 & 5.95538 & 5.22215 & 3.59264 & 0.60326 & 0.00169 & 14.99460 \\
\hline AssetPlasticity $_{i t}$ & 15812 & 3.03286 & 2.45607 & 2.27088 & 0.74876 & 0.00145 & 14.99832 \\
\hline$R I_{i}$ & 2314 & 28.04614 & 21.17888 & 25.42068 & 0.90639 & 1.25667 & 455.3691 \\
\hline$R O E_{i t}$ & 18663 & 0.33265 & 0.25795 & 0.87870 & 2.64155 & 0.00008 & 106.9022 \\
\hline$N_{\text {euro_area_subsidiaries }}$ & 19168 & 5.24708 & 3.00000 & 7.27691 & 1.38685 & 2 & 139 \\
\hline$N$ foreign subsidiaries $_{i}$ & 19168 & 8.94616 & 3.00000 & 26.94797 & 3.01224 & 0 & 383 \\
\hline
\end{tabular}

Table 4. Parametric tests for equality of means and nonparametric tests for equality of medians between the variables used to test our hypotheses

The variables used to test our hypotheses were described in detail in in subsection 3.2 and in table $1 . *^{*}$, * and *** indicate significance of the coefficients at $10 \%, 5 \%$ and $1 \%$ level, respectively. A statistically significant difference, upward or downward, can be proved through the one-sided t-test for mean comparison of two independent subsamples, and assuming unequal variances: diff $>0 * * *$ representing a difference between the mean of the two groups that is statistically significantly greater than zero; diff $<0 * * *$ representing a difference between the mean of the two groups that is statistically significantly less than zero.

Section 1: Parametric tests for equality of means and nonparametric tests for equality of medians between the variables used to test our hypotheses - 10,915 unrelated diversified firm-year observations vs 8,253 related diversified firm-year observations

\begin{tabular}{l|l} 
Mean & Median
\end{tabular}




\begin{tabular}{|c|c|c|c|c|c|c|c|c|}
\hline & $\begin{array}{l}\text { Unrelated } \\
\text { diversified }\end{array}$ & $\begin{array}{l}\text { Related } \\
\text { diversified }\end{array}$ & $\begin{array}{l}\text { Two-sided t- } \\
\text { test }\end{array}$ & $\begin{array}{l}\text { One-sided t- } \\
\text { test }\end{array}$ & $\begin{array}{l}\text { Unrelated } \\
\text { diversified }\end{array}$ & $\begin{array}{l}\text { Related } \\
\text { diversified }\end{array}$ & $\begin{array}{c}\text { Wilcoxon- } \\
\text { Mann-Whitney } \\
\text { test }\end{array}$ & $\begin{array}{c}\text { Nonparametric } \\
\text { equality-of- } \\
\text { medians test }\end{array}$ \\
\hline Performance $_{i t}$ & 0.1048 & 0.1054 & -0.6967 & & 0.0951 & 0.0940 & -0.375 & 0.99 \\
\hline$L D_{i t}$ & 0.7649 & 0.8587 & $-11.0103 * * *$ & $\operatorname{diff}<0 * * *$ & 0.6793 & 0.7436 & $8.315 * * *$ & $96.69 * * *$ \\
\hline FinLev $_{i t}$ & 0.2383 & 0.2388 & -0.1782 & & 0.2276 & 0.2229 & -0.388 & 1.45 \\
\hline Size $_{i t}$ & 11.6980 & 11.7366 & -1.6252 & $\operatorname{diff}<0 *$ & 11.4728 & 11.4651 & 0.985 & 0.06 \\
\hline Tang $_{i t}$ & 0.2363 & 0.2300 & $2.3090 * *$ & $\operatorname{diff}>0 * *$ & 0.2003 & 0.1902 & $-3.627 * * *$ & $5.11 * *$ \\
\hline$M t o B_{i t}$ & 6.0199 & 5.8697 & $2.3996^{* *}$ & $\operatorname{diff}>0 * * *$ & 5.2683 & 5.1787 & $-1.973 * *$ & 1.12 \\
\hline AssetPlasticity $_{i t}$ & 3.0897 & 2.9551 & $3.7024 * * *$ & $\operatorname{diff}>0 * * *$ & 2.5297 & 2.3672 & $-3.897 * * *$ & $17.12 * * *$ \\
\hline$R I_{i}$ & 29.1489 & 26.1613 & $2.929 * * *$ & $\operatorname{diff}>0 * * *$ & 21.6702 & 20.5957 & -0.974 & $4.14 * *$ \\
\hline$R O E_{i t}$ & 0.3390 & 0.3242 & 1.2659 & & 0.2605 & 0.2546 & -1.290 & 2.03 \\
\hline
\end{tabular}

Section 2: Parametric tests for equality of means and nonparametric tests for equality of medians between the variables used to test our hypotheses - 2,160 unlisted vs 236 listed firms

\begin{tabular}{|c|c|c|c|c|c|c|c|c|}
\hline & \multicolumn{4}{|c|}{ Mean } & \multicolumn{4}{|c|}{ Median } \\
\hline & Unlisted & Listed & $\begin{array}{c}\text { Two-sided t- } \\
\text { test }\end{array}$ & $\begin{array}{c}\text { One-sided t- } \\
\text { test }\end{array}$ & Unlisted & Listed & $\begin{array}{c}\text { Wilcoxon- } \\
\text { Mann-Whitney } \\
\text { test }\end{array}$ & $\begin{array}{c}\text { Nonparametric } \\
\text { equality-of- } \\
\text { medians test }\end{array}$ \\
\hline$L D_{i t}$ & 0.7606 & 1.2144 & $-27.5283^{* * *}$ & $\operatorname{diff}<0 * * *$ & 0.6806 & 1.1545 & $-28.19 * * *$ & $509.26 * * *$ \\
\hline$U D_{i t}$ & 0.4046 & 0.6405 & $-22.2318 * * *$ & $\operatorname{diff}<0 * * *$ & 0.3455 & 0.6465 & $-22.93 * * *$ & $298.69 * * *$ \\
\hline$R D_{i t}$ & 0.3560 & 0.5738 & $-17.6230 * * *$ & $\operatorname{diff}<0 * * *$ & 0.1860 & 0.5254 & $-19.93 * * *$ & $222.22 * * *$ \\
\hline FinLev $_{i t}$ & 0.2393 & 0.2313 & $2.2579 * *$ & $\operatorname{diff}>0 * *$ & 0.2256 & 0.2255 & 0.698 & 0.0006 \\
\hline Size $_{i t}$ & 11.4822 & 13.8171 & $-50.3929 * * *$ & $\operatorname{diff}<0 * * *$ & 11.3369 & 13.6062 & $-47.91 * * *$ & $1200.00 * * *$ \\
\hline Tang $_{i t}$ & 0.2324 & 0.2439 & $-2.4568 * *$ & $\operatorname{diff}<0 * * *$ & 0.1944 & 0.2118 & $-2.13 * *$ & $5.58 * *$ \\
\hline Mto $B_{i t}$ & 5.9565 & 5.9457 & 0.1125 & & 5.2142 & 5.2939 & -0.74 & 0.63 \\
\hline AssetPlasticity $_{i t}$ & 3.0214 & 3.1364 & $-1.9094 *$ & $\operatorname{diff}<0 * *$ & 2.4437 & 2.5754 & $-2.641 * * *$ & $4.52 * *$ \\
\hline$R I_{i}$ & 29.9648 & 31.3538 & -0.6128 & & 20.8695 & 25.0015 & $-2.637 * * *$ & $3.49 *$ \\
\hline$R O E_{i t}$ & 0.3339 & 0.3212 & 1.4352 & $\operatorname{diff}>0 *$ & 0.2532 & 0.2839 & $-7.148 * * *$ & $75.44 * * *$ \\
\hline
\end{tabular}

Table 5. Pearson correlation coefficients between variables used to test our hypotheses and variance inflation factor (VIF)

This table reports the Pearson correlation coefficients between the variables (scaled by the $R I$ ) used to test our hypotheses, and the variance inflation factor (VIF) to test for possible multicollinearity problems. Definitions of the variables are listed in subsection 3.2 and in table $1 . *^{*}, *$ and $* * *$ indicate significance of the coefficients at $10 \%, 5 \%$ and $1 \%$ level, respectively.

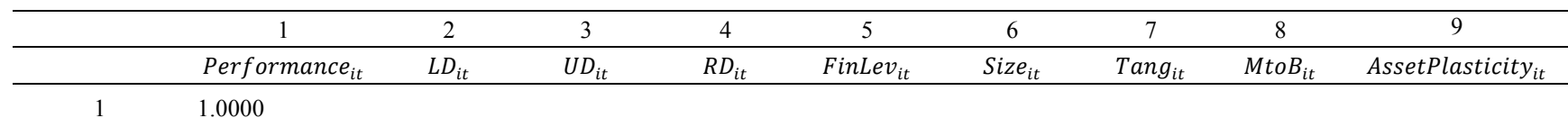




\begin{tabular}{|c|c|c|c|c|c|c|c|c|c|}
\hline 2 & $0.2091 * * *$ & 1.0000 & & & & & & & \\
\hline 3 & $0.1709 * * *$ & $0.6555^{* * *}$ & 1.0000 & & & & & & \\
\hline 4 & $0.1281 * * *$ & $0.7537 * * *$ & -0.0023 & 1.0000 & & & & & \\
\hline 5 & 0.0087 & $0.0920 * * *$ & $0.0627 * * *$ & $0.0672 * * *$ & 1.0000 & & & & \\
\hline 6 & $0.4625 * * *$ & $0.5159 * * *$ & $0.3800 * * *$ & $0.3524 * * *$ & $0.2049 * * *$ & 1.0000 & & & \\
\hline 7 & $0.2562 * * *$ & $0.1069^{* * *}$ & $0.1036^{* * *}$ & $0.0514^{* * *}$ & $0.3115^{* * *}$ & $0.3807 * * *$ & 1.0000 & & \\
\hline 8 & $0.6088 * * *$ & $0.1929 * * *$ & $0.1713 * * *$ & $0.1031 * * *$ & $0.2619 * * *$ & $0.5121 * * *$ & $0.2746^{* * *}$ & 1.0000 & \\
\hline 9 & $0.7088^{* * *}$ & $0.2081^{* * *}$ & $0.1980 * * *$ & $0.1032 * * *$ & $0.1347 * * *$ & $0.4994 * * *$ & $0.2783^{* * *}$ & $0.8146^{* * *}$ & 1.0000 \\
\hline
\end{tabular}

\begin{tabular}{lllllll} 
Equation 4.1 & \multicolumn{1}{l}{} & & \\
\hline VIF & - & 3.57 & 3.13 & 9.11 & 2.81 & 4.15 \\
1/VIF & - & 0.2803 & 0.3198 & 0.1098 & 0.3559 \\
Mean VIF & 4.55 & & & & & \\
\hline
\end{tabular}

\begin{tabular}{|c|c|c|c|c|c|c|c|}
\hline \multicolumn{8}{|c|}{ Equation 4.4} \\
\hline VIF & - & 2.43 & 1.92 & 3.13 & 9.16 & 2.81 & 4.15 \\
\hline Mean VIF & 3.93 & & & & & & \\
\hline
\end{tabular}

\begin{tabular}{llllll} 
Equation 4.5 & & & & & \\
\hline VIF & 1.85 & - & 1.05 & 1.21 & 1.82 \\
1/VIF & 0.5417 & - & 0.9531 & 0.8241 & 0.5498 \\
Mean VIF & & 1.48 & & & \\
\hline
\end{tabular}

\begin{tabular}{|c|c|c|c|c|c|}
\hline Equation 4 & & & & & \\
\hline VIF & 3.56 & 3.05 & 6.82 & 2.80 & - \\
\hline 1/VIF & 0.2809 & 0.3284 & 0.1466 & 0.3577 & - \\
\hline Mean VIF & & & & & 4.06 \\
\hline
\end{tabular}

\begin{tabular}{|c|c|c|c|c|c|c|}
\hline Equation 4.6.2 & & & & & & \\
\hline VIF & 2.43 & 1.91 & 3.05 & 6.91 & 2.80 & - \\
\hline $1 / \mathrm{VIF}$ & 0.4110 & 0.5228 & 0.3283 & 0.1448 & 0.3573 & - \\
\hline Mean VIF & & & & & & 3.42 \\
\hline
\end{tabular}

Table 6. Parameter estimates from panel regressions on the effect of the firm's overall, unrelated and related diversification levels and performance - Eq. (1) and Eq. (4) - H1 and $\mathrm{H} 2$

This table summarizes the estimations on the effect of the firm's overall diversification level on the firm's performance (H1) - column (1) - and the effect of both unrelated and related diversification levels on diversified firms' performance (H2) - column (2) - generated by Blundell and Bond's (1998) system, the GMM estimation method. The data were drawn from the 2010 to 2017 Amadeus files. Definitions of the variables are listed in subsection 3.2 and in table 1. The final two pairs of rows report results for the AR(2) test for the null hypothesis of no second-order serial correlation and Hansen test for the null hypothesis of instruments that are uncorrelated with the disturbances and instruments that are valid (over-identifying restrictions). ${ }^{*}, * *$ and $* * *$ indicate significance at $10 \%, 5 \%$ and $1 \%$, respectively. Values enclosed in parentheses are the $t$ or $z$ statistics for coefficients, and values in square brackets are the $p$-values for test 
statistics.

\begin{tabular}{|c|c|c|}
\hline Independent Variables & $\begin{array}{c}(1) \\
\text { Performance } \\
\text { H1 }\end{array}$ & $\begin{array}{c}(2) \\
\text { Performance } \\
\text { H2 } \\
\text { it }\end{array}$ \\
\hline Performance $_{i t-1}$ & $\begin{array}{c}0.5283^{* * *} \\
(6.08)\end{array}$ & $\begin{array}{c}0.4574 * * * \\
(4.39)\end{array}$ \\
\hline$L D_{i t}$ & $\begin{array}{c}0.0040^{* * *} \\
(3.81)\end{array}$ & \\
\hline$U D_{i t}$ & & $\begin{array}{c}0.0065^{* * * *} \\
(3.65)\end{array}$ \\
\hline$R D_{i t}$ & & $\begin{array}{c}0.0098^{* * *} \\
(6.61)\end{array}$ \\
\hline FinLev $_{i t}$ & $\begin{array}{c}-0.0757^{* * *} \\
(-9.28)\end{array}$ & $\begin{array}{c}-0.0821^{* * * *} \\
(-9.09)\end{array}$ \\
\hline Size $_{i t}$ & $\begin{array}{l}-0.0007 \\
(-1.35)\end{array}$ & $\begin{array}{c}-0.0024 * * \\
(-2.58)\end{array}$ \\
\hline Tang $_{i t}$ & $\begin{array}{c}0.0202 * * * \\
\quad(4.60)\end{array}$ & $\begin{array}{c}0.0282 * * * \\
(5.29)\end{array}$ \\
\hline$M t o B_{i t}$ & $\begin{array}{c}0.0064 * * * \\
(13.89)\end{array}$ & $\begin{array}{c}0.0073^{* * *} \\
(16.26)\end{array}$ \\
\hline Observations & 10823 & 10823 \\
\hline $\mathrm{AR}(2)$ test & $\begin{array}{c}0.86 \\
{[0.389]}\end{array}$ & $\begin{array}{c}0.75 \\
{[0.452]}\end{array}$ \\
\hline Hansen test & $\begin{array}{c}18.16 \\
{[0.111]}\end{array}$ & $\begin{array}{c}17.13 \\
{[0.104]}\end{array}$ \\
\hline Year dummies & Yes & Yes \\
\hline
\end{tabular}


Table 7. Parameter estimates from panel regressions on the relationship between change in firms' levels of asset plasticity and the change in the unrelated diversification levels - Eq. (5) $-\mathrm{H} 3$

This table summarizes the estimations on the change in the levels of firm's asset plasticity on the change in its unrelated diversification levels (H3), generated by Blundell and Bond's (1998) system, the GMM estimation method. The data were drawn from the 2010 to 2017 Amadeus files. Definitions of the variables are listed in subsection 3.2 and in table 1. The final two pairs of rows report results for the AR(2) test for the null hypothesis of no second-order serial correlation and Hansen test for the null hypothesis of instruments that are uncorrelated with the disturbances and instruments that are valid (over-identifying restrictions). *, $* *$ and $* * *$ indicate significance at $10 \%, 5 \%$ and $1 \%$, respectively. Values enclosed in parentheses are the $t$ or $\mathrm{z}$ statistics for coefficients, and values in square brackets are the p-values for test statistics.

\begin{tabular}{|c|c|}
\hline Independent Variables & $\begin{array}{c}(1) \\
\Delta U D_{i t} \\
\mathbf{H 3}\end{array}$ \\
\hline$\Delta U D_{i t-1}$ & $\begin{array}{c}-0.1788^{* * * *} \\
(-5.06)\end{array}$ \\
\hline$\Delta$ Performance ${ }_{i t}$ & $\begin{array}{c}-0.5370 * * \\
(-2.00)\end{array}$ \\
\hline$\Delta$ FinLev $_{i t}$ & $\begin{array}{c}0.0010 \\
(0.01)\end{array}$ \\
\hline$\Delta S i z e_{i t}$ & $\begin{array}{c}0.0249^{* * *} \\
\quad(6.12)\end{array}$ \\
\hline$\Delta$ AssetPlasticity $_{i t}$ & $\begin{array}{c}0.0132 * * * \\
(2.63)\end{array}$ \\
\hline Observations & 10107 \\
\hline $\mathrm{AR}(2)$ test & $\begin{array}{c}0.67 \\
{[0.503]}\end{array}$ \\
\hline Hansen test & $\begin{array}{c}23.95 \\
{[0.004]}\end{array}$ \\
\hline Year dummies & Yes \\
\hline
\end{tabular}

